Barker, P.F., Camerlenghi, A., Acton, G.D., and Ramsay, A.T.S. (Eds.)

Proceedings of the Ocean Drilling Program, Scientific Results Volume 178

\title{
23. NeOGene to QuATERnary Deposition of Opal on the Continental Rise West of the Antarctic Peninsula, ODP LeG 178, SITES 1095, 1096, AND 1101'
}

Claus-Dieter Hillenbrand ${ }^{2}$ and Dieter K. Fütterer ${ }^{2}$

\begin{abstract}
Neogene to Quaternary records of biogenic opal contents and opal accumulation rates are presented for Sites 1095, 1096, and 1101, which were drilled during Ocean Drilling Program Leg 178 in the Bellingshausen Sea, a marginal sea in the eastern Pacific sector of the Southern Ocean. The opal records in the drift sediments on the continental rise west of the Antarctic Peninsula provide signals of paleoproductivity, although they are influenced by dissolution in the water column and the sediment column. Opal contents at Sites 1095, 1096, and 1101 show similar long-term trends through the Neogene and Quaternary, whereas the opal accumulation rates exhibit marked discrepancies, which are caused by local differences in opal preservation linked to local variations of bottom current-induced supply of lithogenic detritus. We used a regression describing the relationship between opal preservation and sedimentation rate to extract the signal of primary opal deposition on the seafloor in the Bellingshausen Sea from the opal accumulation in the drift deposits. On long-term timescales, the reconstructed opal depositional rates show patterns similar to those of the opal contents and a much better coherency between the different locations on the Antarctic Peninsula continental rise. Therefore, the estimated opal depositional rates are suggested to represent a suitable proxy for paleoproductivity in the drift setting of the Bellingshausen Sea.

Supposing that the sea-ice coverage within the Antarctic Zone was the main factor controlling biological productivity in the Bellings-
\end{abstract}

${ }^{1}$ Hillenbrand, C.-D., and Fütterer, D.K., 2001. Neogene to Quaternary deposition of opal on the continental rise west of the Antarctic Peninsula, ODP Leg 178, Sites 1095, 1096, and 1101. In Barker, P.F., Camerlenghi, A., Acton, G.D., and Ramsay, A.T.S. (Eds.), Proc. ODP, Sci. Results, 178, 1-33 [Online]. Available from World Wide Web: <http://www-odp.tamu.edu/ publications/178_SR/VOLUME/ CHAPTERS/SR178_023.PDF>. [Cited YYYY-MM-DD]

${ }^{2}$ Alfred Wegener Institute for Polar and Marine Research, PO Box 1201 61, D-27515 Bremerhaven, Federal Republic of Germany. Correspondence author: chillenbrand@awibremerhaven.de

Initial receipt: 28 August 2000 Acceptance: 6 August 2001

Web publication: 14 November 2001 Ms 178SR-215 


\section{C.-D. HILLENBRAND AND D.K. FÜTTERER NeOgene TO QUATERnARY OPAL Deposition}

hausen Sea, and thus the estimated opal depositional rates on the continental rise, we reconstructed paleoceanographic long-term changes during the Neogene and Quaternary considering the climatic control on regional and global scales. Slightly enhanced opal depositional rates during the late Miocene are interpreted to indicate warmer climatic conditions in the vicinity of the Antarctic Peninsula than at present. The contribution of heat from the Northern Component Water (NCW) into the Southern Ocean seems only to have played a subordinate role during that time. High opal depositional rates during the early Pliocene document a strong reduction of sea-ice coverage and relatively warm climatic conditions in the Bellingshausen Sea. The early onset of the Pliocene warmth points to a positive feedback of regional Antarctic climate on the global thermohaline circulation. A decrease of opal deposition between 3.1 and $1.8 \mathrm{Ma}$ likely reflects sea-ice expansion in response to reduced NCW flow, caused by the onset and intensification of Northern Hemisphere glaciation. Throughout the Quaternary, a relatively constant level of opal depositional rates in the Bellingshausen Sea indicates stable climatic conditions in the Antarctic Peninsula area.

\section{INTRODUCTION}

\section{Scientific Background and Objectives}

Biological productivity in the Southern Ocean has a strong impact on the silica cycle in the World Ocean. Silica is an important nutrient in the marine environment and is utilized by diatoms, silicoflagellates, radiolarians, and sponges to build up their frustules and spicules. It is estimated that up to $37 \%$ of the global biogenic silica accumulation is taking place in Southern Ocean sediments, particularly within the pelagic "opal belt" south of the Polar Front (Ragueneau et al., 2000). Moreover, it is suggested that variations in atmospheric $\mathrm{CO}_{2}$ concentrations, which contributed to the distinct glacial-interglacial cyclicity of the late Quaternary climate, are linked to changes of carbon dioxide uptake in the Southern Ocean (Kumar et al., 1995; Francois et al., 1997; Elderfield and Rickaby, 2000). Therefore, the reconstruction of paleoproductivity in the Southern Ocean and its connection to global environmental changes both on long-term and short-term timescales is of major importance for our understanding of the Earth climatic system.

In the cold surface waters of the Southern Ocean, production of diatoms prevails. Consequently, biogenic components in the underlying deep-sea sediments mainly consist of the remains of this siliceous phytoplankton (e.g., Goodell, 1973). The linkage between biosiliceous production in the euphotic zone and the accumulation of opal within the seabed, however, is quite complex because various processes influence the preservation of the siliceous tests (e.g., Ragueneau et al., 2000). The most important processes are (1) dissolution in the water column and the surficial sediment and (2) sediment redistribution ("winnowing" and "focusing") (Nelson and Gordon, 1982; van Bennekom et al., 1988; Francois et al., 1997; Schlüter et al., 1998; Frank et al., 2000; Pondaven et al., 2000). Furthermore, supply of lithogenic and/or calcareous particles controls the opal concentrations in the sediment by both dilution and preservation effects (Archer et al., 1993; DeMaster et al., 1996; Ragueneau et al., 2000). Therefore, the potential influence of these processes on the opal record, which is archived in the sediments, needs to 
be considered when using the opal signal as a proxy for paleoproductivity. Nevertheless, opal records in upper Quaternary sedimentary sequences from the Bellingshausen Sea apparently reflect climaticinduced productivity changes in the surface waters (Pudsey and Camerlenghi, 1998; Hillenbrand, 2000; Pudsey, 2000).

In this chapter, we present contents and accumulation rates of biogenic opal in upper Miocene to Quaternary drift sediments recovered on the continental rise west of the Antarctic Peninsula. We will discuss how dissolution processes and supply of nonbiosiliceous particles have affected opal preservation in the drift deposits. It will be shown that the opal record can be used as a proxy for the reconstruction of relative productivity changes in the polar Southern Ocean on long-term timescales, although the original productivity signal is masked. We highlight how both regional paleoclimatic conditions and Southern Ocean circulation, which is strongly coupled to global paleoceanography, influenced the productivity changes observed in the high-latitude environment west of the Antarctic Peninsula.

\section{Regional Setting}

Sites 1095, 1096, and 1101 are located in the Bellingshausen Sea, which represents a marginal sea in the Pacific sector of the Southern Ocean (Fig. F1). These sites were drilled on the upper continental rise west of the Antarctic Peninsula, which is characterized by nine large sediment mounds, elevated up to $900 \mathrm{~m}$ above the surrounding seafloor (Rebesco et al., 1996, 1998). The mounds, which were interpreted as asymmetric contourite drifts, are elongated toward the abyssal plain and are separated by $5-\mathrm{km}$-wide and 150 -m-deep channels originating in dendritic feeder gullies at the base of the continental slope.

All three sites are located within the Antarctic Zone that is bounded by the Polar Front in the north and by the southern boundary of the clockwise flowing Antarctic Circumpolar Current (ACC) in the south (Orsi et al., 1995). Because of seasonal sea-ice coverage, open-water conditions in this zone prevail only during spring and summer, for about 8 months above Drift 4 and for about 3 months above Drift 7 (Parkinson, 1994). During these periods, light permeates the surface waters and thus promotes phytoplankton productivity. The water column in the Bellingshausen Sea includes a thin surface layer of cold Antarctic Surface Water (AASW), underlain by warm, saline Circumpolar Deep Water (CDW), which locally protrudes onto the continental shelf (Hofmann et al., 1996). CDW in the Pacific sector of the Southern Ocean represents a mixture of North Atlantic Deep Water (NADW) and recirculated waters from the Indian and Pacific Oceans (Patterson and Whitworth, 1990). The flow of relatively warm NADW to the Southern Ocean is assumed to govern the heat budget of the CDW (e.g., Denton, 2000). Warmth delivered by the CDW has a strong impact on the overlying surface waters and on the survival of sea ice (e.g., Hofmann et al., 1996; Jacobs and Comiso, 1997).

Along the flanks of Drift 7, bottom-water flow with a mean current velocity of $\sim 6 \mathrm{~cm} / \mathrm{s}$ follows the bathymetric contours in an counterclockwise manner (Camerlenghi et al., 1997). The contour current was concluded to represent the southwestward extension of Weddell Sea Deep Water (WSDW) (Camerlenghi et al., 1997), which leaves the Weddell Sea via deep topographic gaps in the South Scotia Ridge and flows along the lower continental slope around the northern tip of the Antarctic Peninsula up to at least $65^{\circ} \mathrm{W}$ (Nowlin and Zenk, 1988). On the
F1. Bathymetric map of the continental margin west of the Antarctic Peninsula, p. 23.

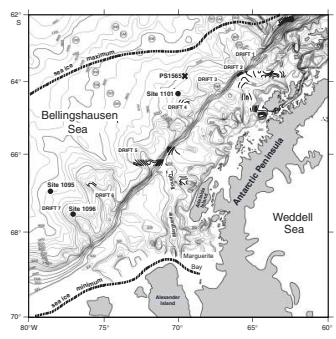


other hand, gradients in dissolved oxygen, nutrients, and density within the bottom water of the Bellingshausen Sea are interpreted to indicate a confinement of WSDW to the South Shetland Trench (Sievers and Nowlin, 1984) and an eastward supply of bottom water from the ACC to the Antarctic Peninsula continental rise (Chernaykova and Stunzhas, 1998; Orsi et al., 1999). A bottom-water circulation from west to east, however, might be precluded at least for the upper continental rise because such a flow pattern would contradict the current directions measured near Drift 7.

\section{MATERIAL AND METHODS}

\section{Core Material and Sampling}

During ODP Leg 178, a nearly complete upper Miocene to Quaternary sequence was recovered from Holes 1095A and 1095B on the distal flank of Drift 7, whereas a complete lower Pliocene to Quaternary sequence was recovered from Holes 1096A, 1096B, and 1096C near the crest of this drift (Fig. F1; Table T1). A complete upper Pliocene to Quaternary sequence was recovered from Hole 1101A at the center of the smaller Drift 4 in the northeast (Fig. F1; Table T1). At all three sites, the recovered sediments generally consist of thin-bedded, bioturbated to massive diatom-bearing muds with common foraminifers, alternating with thick-bedded, lithogenic, mainly fine-grained laminites (Barker, Camerlenghi, Acton, et al., 1999). The intervals with higher biogenic contents were interpreted as hemipelagites deposited during interglacials, whereas the lithogenic laminites were described as distal turbidites and contourites deposited during glacials. Throughout the Neogene and Quaternary, all sediments were deposited in a glaciomarine environment as indicated by the presence of ice-rafted debris (IRD). At distal Site 1095, turbidites are more abundant than at the drift-crest Sites 1096 and 1101. According to smear slide analyses, the siliceous microfossil assemblages at all three sites predominantly consist of diatoms with abundant sponge spicules, rare silicoflagellates, and rare radiolarians (Barker, Camerlenghi, Acton, et al., 1999).

Opal contents were analyzed on 863 samples from sediment cores recovered at ODP Leg 178 Sites 1095, 1096, and 1101 (Table T1). The sample spacings correspond to time intervals of 31 k.y. for Site 1095, 11 k.y. for Site 1096, and 22 k.y. for Site 1101. At Site 1095, the samples were taken from Holes 1095A and 1095B, and at Site 1096, the samples were taken from Holes 1096A, 1096B, and 1096C. Thus, for these sites, depths in meters below seafloor (mbsf) were recovery corrected and converted to meters composite depths (mcd) using the corrections given in Barker, Camerlenghi, Acton, et al. (1999). At Site 1101, samples were only taken from one hole (Hole 1101A), and depths are therefore given as recovery-corrected meters below seafloor (rmbsf). The samples used in this study represent splits from $10-\mathrm{cm}^{3}$ samples taken on board for determinations of $\mathrm{CaCO}_{3}$ and total organic carbon (TOC) contents (Wolf-Welling et al., Chap. 15, this volume).

Contents and accumulation rates of biogenic opal, TOC, $\mathrm{CaCO}_{3}$, and biogenic barium $\left(\mathrm{Ba}_{\mathrm{bio}}\right)$ from sediments deposited at gravity core site PS1565 are shown to compare various palaeoproductivity proxies. Site PS1565 is located at the seaward termination of Drift 3 (Fig. F1). The data presented for this sediment core were previously published in Hillenbrand (2000). All raw data presented in this study are available from
T1. Samples drilled on the continental rise west of the Antarctic Peninsula, p. 32. 
the PANGAEA data bank of the Alfred Wegener Institute for Polar and Marine Research, Bremerhaven, Germany (http://www.pangaea.de).

\section{Analytical Procedure}

We analyzed the opal-A content of 20-mg homogenized dry bulk sediment samples using an automated leaching technique after Müller and Schneider (1993), which was shown to be reliable in an interlaboratory comparison (Conley, 1998). Silicon was extracted by wet-chemical means with 1-M NaOH, and concentrations of dissolved silicon were measured by molybdate-blue spectrophotometry. The proportion of biogenic silicon was determined by graphical analysis of the absorbance vs. time plot (DeMaster, 1981). Resulting silicon values were converted into weight percent biogenic $\mathrm{SiO}_{2}$ and are given as weight percent opal by assuming a uniform bound water content of $10 \mathrm{wt} \%$ within the opaline substance. According to Müller and Schneider (1993), the relative accuracy of the method is better than $2 \%$ for samples rich in biogenic silica and $4 \%-10 \%$ for samples with $<10 \mathrm{wt} \%$ biogenic silica, respectively. To estimate the precision of our laboratory array we analyzed three sediment samples repeatedly, yielding a relative accuracy between $2 \%$ and $5 \%$ with no systematic variation (Table T2). For the method used, Bonn et al. (1998) assumed an artificial background value of 1-2 wt\% "pseudo-opal," caused by a partial leaching of clay minerals. In contrast, we measured opal contents down to $0.4 \mathrm{wt} \%$ on discrete samples, suggesting a negligible background opal signal. Therefore, no correction for possible background values was made.

\section{Stratigraphy}

The age models for Sites 1095, 1096, and 1101 were computed by linear interpolation between magnetostratigraphic datums given in Barker, Camerlenghi, Acton, et al. (1999), using the timescale of Berggren et al. (1995). Our estimated linear sedimentation rates differ slightly from the sedimentation rates given by Barker, Camerlenghi, Acton, et al. (1999) because we referred the paleomagnetic ages to recovery-corrected composite depths and recovery-corrected depths below seafloor, respectively. The paleomagnetic age model for Site 1096 was refined by including the Reunion Event (Chron 2r.1n), which was identified in Core 178-1096C-2H (G. Acton, pers. comm., 1999). At Site 1095, we additionally considered a possible hiatus within the upper Pliocene sedimentary sequence (Barker, Camerlenghi, Acton, et al., 1999). The paleomagnetic data indicate that the hiatus spans the earliest Matuyama Chron (C2r) and the onset of the Olduvai Event (C2n). Assuming nondeposition or erosion for the corresponding time between 2.581 and $1.770 \mathrm{ka}$, we calculated a linear sedimentation rate of $5.0 \mathrm{~cm} / \mathrm{k} . \mathrm{y}$. for the late Gauss Chron (C2An.1n). This value agrees well with the sedimentation rate of $4.8 \mathrm{~cm} / \mathrm{k} . \mathrm{y}$. calculated for the sediments deposited during the late Matuyama Chron. There is biostratigraphic evidence for another hiatus at Site 1095, spanning the time interval between 6.140 and $5.040 \mathrm{ka}$ (M. Iwai, pers. comm., 2001). We did not consider this possible hiatus in the calculation of the age model for Site 1095 , but we considered nondeposition or erosion during that time interval in the discussion section. For a better accentuation of long-term trends, we additionally resampled the data sets of opal at Sites 1095, 1096, and 1101 by linear integration at equal time increments of 200 k.y., applying the AnalySeries software (Paillard et al., 1996).
T2. Results of repeated opal measurements, p. 33. 


\section{Calculation of Opal Accumulation Rates}

Opal accumulation rates $\left(\mathrm{MAR}_{\mathrm{opal}}\right.$, in grams per square meter per year) were calculated by multiplying linear sedimentation rates (LSRs) with the proportions of biogenic silica and dry bulk densities measured on board ship (Barker, Camerlenghi, Acton, et al., 1999). For this purpose, the data sets of opal and dry density were resampled by linear integration at equal time increments, applying the AnalySeries software (Paillard et al., 1996). For Site 1095, time increments of 20 k.y. were used for the interval from 9.580 to $2.580 \mathrm{ka}$ and increments of $50 \mathrm{k} . \mathrm{y}$. were chosen for the interval from 1.750 to $0 \mathrm{ka}$. Equal time increments of 10 and 20 k.y. were used for Site 1096 and Site 1101, respectively. The chosen time increments correspond to the average temporal resolution of the opal data sets.

\section{RESULTS}

\section{Opal Contents}

The opal concentrations at Sites 1095, 1096 and 1101 are plotted vs. depth in Figure F2 and vs. age in Figure F3. Figure F3 also includes time series of opal contents integrated linearly at time increments of $200 \mathrm{k} . \mathrm{y}$.

\section{Site 1095}

At Site 1095, only two closely spaced samples taken from sediments, which are early late Miocene in age $(562-510 \mathrm{mcd})$, were investigated for opal. Both samples revealed low opal contents on the order of 5 wt $\%$ (Figs. F2, F3). The low opal values might not be representative for the whole lower part of the upper Miocene sequence at Site 1095, but a low opal concentration is also indicated by low diatom abundance within this poorly recovered sequence (Barker, Camerlenghi, Acton, et al., 1999). The sediments spanning the middle and upper parts of the upper Miocene (510-178 mcd) are characterized by opal contents that predominantly vary between 8 and $20 \mathrm{wt} \%$ around a mean value of 13 $\mathrm{wt} \%$. Opal concentrations in this sequence are especially low in distinct samples in which partly recovered coarse-grained layers represent distal turbidites (e.g., at $199 \mathrm{mcd}$ ). The long-term trend in opal concentrations at Site 1095 exhibits a general decrease through the upper Miocene, with relative minima centered at $\sim 7.8, \sim 6.6$, and $\sim 5.6 \mathrm{Ma}$.

The opal contents in sediments that are early Pliocene to early late Pliocene in age (178-90 mcd) predominantly fluctuate between 10 and $25 \mathrm{wt} \%$ around a relatively high mean value of $17 \mathrm{wt} \%$. As in the older sediments, low opal amounts were measured in partly sampled distal turbidites. Within the rest of the upper Pliocene sequence $(90-65 \mathrm{mcd})$, the mean opal contents exhibit a clear upward decrease with high frequent variations with an amplitude of $3 \mathrm{wt} \%$. The Quaternary sediments (65-0 mcd) are separated from the upper Pliocene sequence by a hiatus. Opal contents in the Quaternary sediments, which have a temporal resolution of only $\sim 50$ k.y., vary around a mean value of $7 \mathrm{wt} \%$ with an amplitude of $5 \mathrm{wt} \%$, thereby showing no significant long-term trend. Diatom abundances counted in samples taken from the upper Miocene to Quaternary sequence at Site 1095 exhibit a very similar pattern as the opal contents (Pudsey, Chap. 25, this volume).
F2. Biogenic opal contents vs. depth, p. 24.

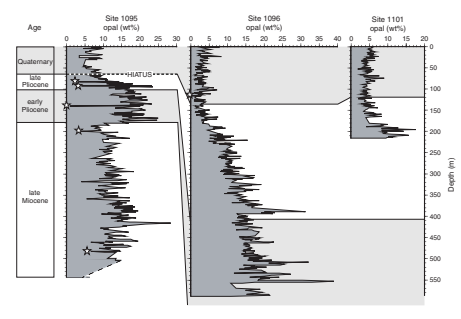

F3. Opal contents vs. age, p. 25.

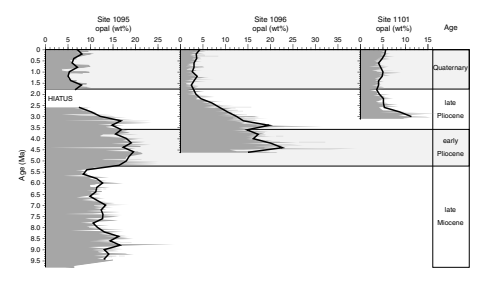




\section{C.-D. HILLENBRAND AND D.K. FÜTTERER

\section{Site 1096}

At Site 1096, opal concentrations in sediments deposited during the early Pliocene and the early late Pliocene (589-305 mcd) exhibit opal fluctuations from 10 to $40 \mathrm{wt} \%$ around a mean opal value of $17 \mathrm{wt} \%$ (Figs. F2, F3). A significant decrease of the opal contents to a value of 3 $\mathrm{wt} \%$ characterizes the rest of the upper Pliocene sequence (305-139 mcd). The amplitude of opal variations in these sediments is 3 to 5 wt $\%$. The Quaternary sediments at Site 1096 (139-0 mcd) comprise a mean opal content of $3.2 \mathrm{wt} \%$, superimposed by fluctuations with an amplitude of only 2 to $3 \mathrm{wt} \%$. The opal contents within the Quaternary sequence exhibit a slight increase upward, reaching $7.8 \mathrm{wt} \%$ in the surface sediment sample. A similar increase is also observed in diatom abundance (Pudsey, Chap. 12, this volume). A sample taken at 114.8 mcd $(178-1096 \mathrm{~B}-13 \mathrm{H}-3,45-47 \mathrm{~cm})$ recovered exclusively a sandy turbidite, yielding an opal content of only $0.4 \mathrm{wt} \%$ (Fig. F2).

\section{Site 1101}

The opal contents in the upper Pliocene sequence at Site 1101 (216$121 \mathrm{rmbsf}$ ) show a systematic upward decrease from values higher than $10 \mathrm{wt} \%$ down to values on the order of $4 \mathrm{wt} \%$. Small-scale fluctuations with an amplitude of $\sim 5 \mathrm{wt} \%$ are superimposed on this trend. Within the Quaternary sediments at Site 1101 (121-0 rmbsf), the opal concentrations predominantly vary between 3 and $6.5 \mathrm{wt} \%$ around a mean value of $4.6 \mathrm{wt} \%$ and exhibit a slight increase, which was also observed at Site 1096. Opal contents at Site 1101 confirm diatom counts (Pudsey, Chap. 12, this volume).

\section{Opal Accumulation Rates}

The accumulation rates of biogenic opal $\left(\mathrm{MAR}_{\text {opal }}\right)$ at Sites 1095, 1096, and 1101 are plotted together with the LSR vs. age in Figure F4.

\section{Site 1095}

$\mathrm{MAR}_{\text {opal }}$ at Site 1095 shows a general decrease throughout the Neogene and Quaternary, varying from $25 \mathrm{~g} / \mathrm{m}^{2}$ per yr during the early part of the late Miocene to $1 \mathrm{~g} / \mathrm{m}^{2}$ per yr during the late Quaternary with some $\mathrm{MAR}_{\text {opal }}$ spikes of up to $60 \mathrm{~g} / \mathrm{m}^{2}$ per yr occurring in the early part of the late Miocene. A positive correlation between $\mathrm{MAR}_{\text {opal }}$ and LSR is observed at Site 1095.

\section{Site 1096}

At Site 1096, MAR $_{\text {opal }}$ slightly declined throughout the Pliocene from $40 \mathrm{~g} / \mathrm{m}^{2}$ per yr during the early Pliocene down to $27 \mathrm{~g} / \mathrm{m}^{2}$ per yr at 2.6 Ma. A major drop down to $12 \mathrm{~g} / \mathrm{m}^{2}$ per $\mathrm{yr}$ in $\mathrm{MAR}_{\text {opal }}$ occurred at 2.6 Ma. Throughout the rest of the late Pliocene, $\mathrm{MAR}_{\text {opal }}$ slightly declined to 3 $\mathrm{g} / \mathrm{m}^{2}$ per yr. Values on this order were obtained from the entire Quaternary section. The highest $\mathrm{MAR}_{\text {opal }}$ between 4.6 and $2.6 \mathrm{Ma}$ are linked to LSRs higher than $15 \mathrm{~cm} / \mathrm{k} . \mathrm{y}$.
F4. Opal accumulation rates vs. age, p. 26.

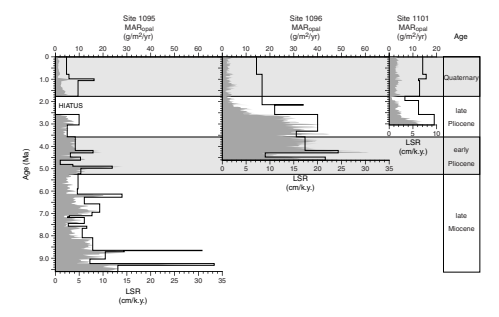


Site 1101

At Site $1101, \mathrm{MAR}_{\text {opal }}$ is $12 \mathrm{~g} / \mathrm{m}^{2}$ per yr between 3.0 and $2.8 \mathrm{Ma}$ and declines to $1 \mathrm{~g} / \mathrm{m}^{2}$ per yr at $1.9 \mathrm{Ma}$. Throughout the Quaternary, mean $\mathrm{MAR}_{\text {opal }}$ at Site 1101 is $3 \mathrm{~g} / \mathrm{m}^{2}$ per yr.

\section{DISCUSSION}

\section{Opal in Drift Sediments West of the Antarctic Peninsula: A Proxy for Biological Productivity or a Preservation Signal?}

\section{Dissolution in the Water Column and at the Sediment- Water Interface}

Biosiliceous particles produced in ocean surface waters partly or completely dissolve while they settle through the water column because of the undersaturation of seawater with respect to silica. Dissolution predominantly takes place within the ocean surface layer and at the sediment water interface (e.g., Nelson and Gordon, 1982; van Bennekom et al., 1988). In order to assess the possible effects of these dissolution processes on the opal record in the study area, we would need detailed analyses regarding production, dissolution, and accumulation of opal in surface sediments, which are not available for the Bellingshausen Sea, but are for the Ross Sea and the Weddell Sea (DeMaster et al., 1996; Nelson et al., 1996; Schlüter et al., 1998). These marginal seas of the Southern Ocean represent environmental and depositional settings comparable to those in the Bellingshausen Sea because the biological productivity in the surface waters is mainly controlled by the sea-ice cover, the slope and rise sediments predominantly consist of lithogenic components, and the Holocene sedimentation rates vary between 1 and $10 \mathrm{~cm} / \mathrm{k} . y$. (DeMaster et al., 1996; Bonn et al., 1998; Schlüter et al., 1998). In the Ross Sea and the Weddell Sea, the concentrations of dissolved silica in the bottom waters bathing the continental slope and rise are typically 120-135 $\mu \mathrm{mol} / \mathrm{L}$ (Jacobs, 1989; Rutgers van der Loeff and van Bennekom, 1989). These values are consistent with the dissolved silica concentration of $120 \mu \mathrm{mol} / \mathrm{L}$ measured on a bottom-water sample above Site 1096 (J. Schuffert, pers. comm., 2000), indicating that at least recently the WSDW in the Bellingshausen Sea is not more corrosive to opal than bottom waters in the Ross and Weddell Seas. Thus, we can assume that opal dissolution processes in the water column and the surface sediments of the Bellingshausen Sea are similar to those in the Ross Sea and the Weddell Sea.

At the continental margins in the Ross Sea and the Weddell Sea, the ratio of opal accumulation in the surface sediments to primarily produced opal in the surface water was estimated to be $0.1 \%-10 \%$ (DeMaster et al., 1996; Nelson et al., 1996; Schlüter et al., 1998). For the surface sediment sample at Site 1096, we computed a $\mathrm{MAR}_{\text {opal }}$ of $2.8 \mathrm{~g} /$ $\mathrm{m}^{2}$ per yr, assuming a Holocene sedimentation rate of $4 \mathrm{~cm} / \mathrm{k}$.y. (Pudsey and Camerlenghi, 1998). According to Ragueneau et al. (2000) the biogenic silica production rate in the seasonal ice-covered Pacific sector of the Southern Ocean is $408 \mathrm{mg} \mathrm{opal} / \mathrm{m}^{2}$ per day. On the condition that the sea-ice limited productivity season above Site 1096 lasts 90 days per $\mathrm{yr}$, the modern ratio of opal accumulation to opal production is $\sim 8 \%$ in 
the Bellingshausen Sea. This value is consistent with the ratios given for the Ross and Weddell Seas.

\section{Dissolution within the Sediment Column}

Diagenetic dissolution of opal within the sediment column predominantly takes place in the surficial sediments (e.g., Schlüter et al., 1998), as also revealed by dissolved silica concentrations in pore water profiles at Sites 1095, 1096, and 1101 (Barker, Camerlenghi, Acton, et al., 1999). Late diagenetic dissolution apparently did not significantly bias the primary opal fluctuations in the older, deeper buried sediments at Sites 1095, 1096, and 1101 because the dissolved silica concentrations conform with contents in siliceous microfossils and, thus, the opal concentrations (Barker, Camerlenghi, Acton, et al., 1999). A bottom-simulating reflector (BSR) observed in seismic profiles across Drift 7 was interpreted to be caused by the diagenetic transformation of opal-A to opal-CT (Rebesco et al., 1997). This BSR was reached by drilling at the base of Site 1095 (Camerlenghi et al., 2001). Therefore, we consider that the opal concentrations in the two lowermost samples at Site 1095 may have been biased by opal diagenesis.

\section{Comparison of the Opal Record with Other Paleoproductivity Proxies}

In spite of the various dissolution processes, opal records in upper Quaternary sediments from the Bellingshausen Sea were interpreted in terms of a proxy for climatic-induced productivity changes in the surface waters (Pudsey and Camerlenghi, 1998; Hillenbrand, 2000; Pudsey, 2000). This assertion is based on the close correspondence between the records of opal and biogenic barium. The biogenic barium signal is assumed to be resistant to dissolution processes in the Antarctic continental rise setting, where oxic conditions prevail in the sediment column (Shimmield et al., 1994; Bonn et al., 1998). At gravity core site PS1565, located between Drifts 3 and 4 (Fig. F1), both contents $\left(\mathrm{Ba}_{\text {bio }}\right)$ and accumulation rates $\left(\mathrm{MAR}_{\mathrm{Ba}}\right.$ bio $)$ of biogenic barium in sediments deposited during the last 130 k.y. positively correlate with opal contents and $\mathrm{MAR}_{\text {opal, }}$ whereas contents of TOC and $\mathrm{CaCO}_{3}$ as well as accumulation rates of $\mathrm{TOC}\left(\mathrm{MAR}_{\mathrm{TOC}}\right)$ and $\mathrm{CaCO}_{3}\left(\mathrm{MAR}_{\mathrm{CaCO}}\right)$ show remarkable discrepancies in respect to $\mathrm{MAR}_{\mathrm{Ba} \text { bio }}$ (Figs. F5, F6). These findings suggest that the opal signal is a more reliable proxy for paleoproductivity in respect to $\mathrm{TOC}$ and $\mathrm{CaCO}_{3}$.

\section{Opal Contents vs. Opal Accumulation Rates}

In general, $\mathrm{MAR}_{\text {opal }}$ is controlled by the deposition and the preservation of opal, whereas the opal content is additionally influenced by the dilution with other sedimentary components. In the drift sediments of the Bellingshausen Sea, lithogenic components chiefly operate as diluting agents. No significant discrepancies between the records of opal contents and $\mathrm{MAR}_{\text {opal }}$ are observed in the upper Quaternary sediments at site PS1565, where LSR exhibited hardly any fluctuations (Figs. F5, F6). Also at Sites 1096 and 1101, the long-term patterns of opal concentrations and $\mathrm{MAR}_{\text {opal }}$ show only minor discrepancies (Figs. F3, F4), suggesting that the record of opal contents in the drift-crest sediments was not masked significantly by the dilution with lithogenous particles. At
F5. Biogenic opal, TOC, $\mathrm{CaCO}_{3}$, and biogenic barium vs. depth, p. 27.

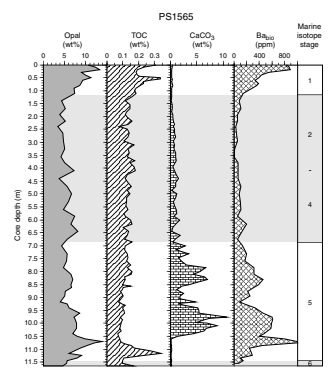

F6. LSR and accumulation rates of opal, TOC, calcite, and biogenic barium vs. age, p. 28.

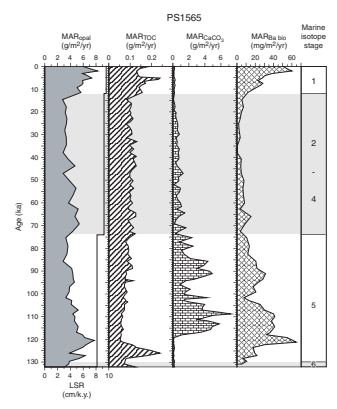


Site 1095, however, no connection between the long-term trends of opal contents and $\mathrm{MAR}_{\text {opal }}$ is observed. $\mathrm{MAR}_{\text {opal }}$ generally declines throughout the last 9.5 m.y., thereby exhibiting spikes during time intervals with high LSR (Fig. F4), whereas the opal concentrations show different long-term variations (e.g., a prominent maximum between 5.3 and 3.0 Ma) (Fig. F3). This disconnection seems to point to a major influence of lithogenic dilution on the opal contents at drift-flank Site 1095.

\section{Effects of Lateral Sediment Supply on Opal Accumulation Rates}

The relationship between $\mathrm{MAR}_{\text {opal }}$ in the sediments and original depositional rates of siliceous particles onto the seabed is strongly affected by the supply of other sedimentary constituents, so that changes of LSR play a major role for opal preservation (e.g., Archer et al., 1993; Ragueneau et al., 2000). For the Antarctic continental margin in the Ross Sea, DeMaster et al. (1996) found a positive correlation between the LSR and the "opal seabed preservation efficiency" (that is, the ratio of $\mathrm{MAR}_{\text {opal }}$ in the surface sediment to the original opal deposition on the seabed) for LSR varying from 0 to $20 \mathrm{~cm} / \mathrm{k} . \mathrm{y}$. (Fig. F7). Moreover, $\mathrm{MAR}_{\text {opal }}$ is often affected by lateral redistribution of biosiliceous particles by bottom currents (e.g., Frank et al., 2000; Pondaven et al., 2000). Accumulation rates of biogenic components in late Quaternary continental margin deposits in the Ross and Weddell Seas were shown to be influenced by bottom current-induced lateral supply of biogenic particles ("focusing"), which may contribute up to two times more biogenic matter than vertical particle rain (Frank et al., 1995; Ceccaroni et al., 1998).

The bottom-current flow on the Antarctic Peninsula continental rise probably acted as a focusing mechanism, too. It has to be stated here that the high sedimentation rates at the drift sites in the Bellingshausen Sea gave the reason for choosing them for deep-sea drilling. We suppose, however, that the direct lateral supply of opal to Sites 1095, 1096, and 1101 was not as important for the $\mathrm{MAR}_{\text {opal }}$ at these locations as the better opal preservation caused by the embedding with laterally delivered lithogenic detritus. The particles entrained in the bottom current are assumed to derive from vertical settling through the water column during interglacial periods and from turbidity currents during glacial episodes (e.g., Barker Camerlenghi, Acton et al., 1999; Pudsey, 2000). The vertical settling matter probably comprised a significant amount of biosiliceous particles, but we expect that its current-controlled redistribution to the drift sites has accentuated the interglacial productivity signal delivered from the overlying water column even more.

In contrast, the turbidity currents originated from unstable locations at the Antarctic Peninsula continental slope, which are unfavorable for vast accumulation of biosiliceous particles. Therefore, the resuspended sediments should predominantly consist of lithogenic components. This assumption is supported by the low opal contents in distal turbidites deposited at the drift sites (Fig. F2). Nevertheless, the extensive occurrence of reworked diatoms at Sites 1095, 1096, and 1101 points to a redistribution of biosiliceous matter from the shelf down to the continental rise, even though its proportion never biased the microfossil assemblages deposited from the overlying water column (Barker, Camerlenghi, Acton et al., 1999). Also, the accumulation of biosiliceous
F7. Correlation between opal seabed preservation efficiency and LSR, p. 29.

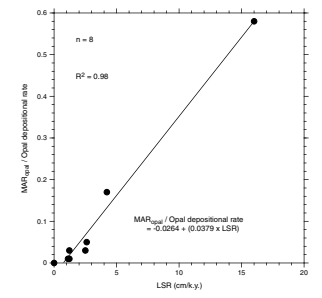




\section{C.-D. HILLENBRAND AND D.K. FÜTTERER NeOgene TO QUATERnARY OPAL Deposition}

matter at gravity core site PS1565 throughout the glacial marine isotope Stages 4-2 (Fig. F6) may indicate the supply of reworked opal because we would not expect any significant opal deposition at least for the last glacial maximum, when permanent sea-ice coverage prevailed above site PS1565 (CLIMAP Project Members, 1981). Therefore, the MAR opal computed for Sites 1095, 1096, and 1101 probably comprises a lateral supply of opal, but its contribution is supposed not to have crucially altered the original opal productivity signal.

The effect of better opal preservation caused by lateral supply of lithogenic detritus is clearly documented in the $\mathrm{MAR}_{\text {opal }}$ at Sites 1095 and 1096. Because of the proximity of both locations (Fig. F1), the production of opal in the surface waters, its flux to the seabed, and the opal accumulation in the sediments should be comparable. In contrast, major discrepancies in $\mathrm{MAR}_{\text {opal }}$ occur between Sites 1095 and 1096 throughout the last 4.6 m.y., especially during time intervals when LSR differed markedly (Fig. F4). Between 4.6 and $2.6 \mathrm{Ma}, \mathrm{MAR}_{\text {opal }}$ at Site 1096 was about five times higher than at Site 1095, and between 1.7 and $0 \mathrm{Ma}, \mathrm{MAR}_{\text {opal }}$ at Site 1096 was about one-third higher than at Site 1095. Thus, we argue that the continuously higher $\mathrm{MAR}_{\text {opal }}$ at Site 1096 with respect to Site 1095 chiefly reflects a better preservation of biosiliceous particles caused by the higher LSR at the crest of Drift 7 with regard to its distal flank. Moreover, we conclude that at Sites 1095, 1096, and 1101, where the LSR varied markedly (Fig. F4), the effect of lateral sediment supply on opal preservation has to be considered, whereas it may be neglected at site PS1565, where LSR exhibited hardly any fluctuation (Fig. F6).

\section{Estimation of Opal Depositional Rates for Sites 1095, 1096, and 1101}

We used the close relationship between the opal preservation efficiency and the LSR found for continental margin sediments in the Ross Sea (DeMaster et al., 1996) to decipher the signal of the original opal depositional rate on the seabed from the $\mathrm{MAR}_{\text {opal }}$ record at Sites 1095, 1096, and 1101. The validity to adopt this approach for the investigated drift sediments in the Bellingshausen Sea arises from the similarity of the depositional settings and the fact that the LSRs at Sites 1095, 1096, and 1101 were $<20 \mathrm{~cm} / \mathrm{k}$.y. throughout most of the Neogene and Quaternary (Fig. F4). The linear regression shown in Figure F7 can be expressed by the following equation:

Opal depositional rate $\left[\mathrm{g} / \mathrm{m}^{2} / \mathrm{yr}\right]=$
$\operatorname{MAR}_{\text {opal }}\left[\mathrm{g} / \mathrm{m}^{2} / \mathrm{yr}\right] /(-0.0264+0.0379[\mathrm{k} . \mathrm{y} . / \mathrm{cm}] \times \operatorname{LSR}[\mathrm{cm} / \mathrm{k} . \mathrm{y}]$.

The resulting opal depositional rates for Sites 1095, 1096, and 1101, including mean values for 200-k.y. time intervals, are shown in Figure F8. For LSRs much higher than $20 \mathrm{~cm} / \mathrm{k}$.y. the regression curve between opal preservation efficiency and LSR can be no longer linear and an asymptotic approach of the regression curve to a value of $100 \%$ preservation efficiency is expected instead. This is documented by an opal preservation efficiency of $86 \%$ for settings with a LSR of $250 \mathrm{~cm} / \mathrm{k} . \mathrm{y}$. (DeMaster et al., 1996). Therefore, at Site 1095 we equated the opal depositional rates with the $\mathrm{MAR}_{\text {opal }}$ for the time intervals between 9.308 and 9.230 and between 8.651 and $8.635 \mathrm{ka}$, when LSRs exceeded 30 $\mathrm{cm} /$ k.y. (Fig. F4).
F8. Estimated opal depositional rates vs. age, p. 30.

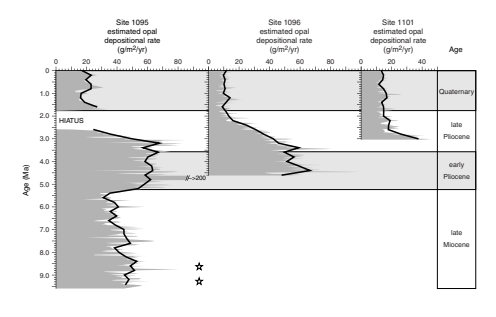


At Site 1095, an extremely high opal depositional rate of $200 \mathrm{~g} / \mathrm{m}^{2}$ per yr was inferred for the time period from 4.890 to $4.620 \mathrm{ka}$, when the LSR was $1.03 \mathrm{~cm} / \mathrm{k} . \mathrm{y}$. Our approach should be valid for this relatively low LSR because the linear correlation of opal preservation efficiency with LSR was established mainly on LSRs in this order (Fig. F7), but such a high opal depositional rate is only typical for deep basins on the inner Antarctic shelf (DeMaster et al., 1996). The nonrealistic high value obtained for Site 1095 may indicate that the opal concentration preserved in the corresponding sample is too high for the supposed LSR. We consider that only one sample was analyzed for opal from the time interval between 4.890 to $4.620 \mathrm{ka}$ and that the assumption of a constant LSR may be wrong for the whole period of time (cf. Froelich et al., 1991). On the other hand, a hiatus suggested to span the time interval from 6.140 to $5.040 \mathrm{ka}$ at Site 1095 (M. Iwai, pers. comm., 2001) would also affect the LSR between 4.890 and 4.620 ka and ultimately result in continuously realistic values for the opal depositional rate. Therefore, the nonrealistic high value was ignored in the calculation of the long-term trend of opal depositional rates at Site 1095.

During the late Miocene, estimated opal depositional rates at Site 1095 predominantly varied between 30 and $50 \mathrm{~g} / \mathrm{m}^{2}$ per yr with relative minima centered at $\sim 7.8, \sim 6.6$, and $\sim 5.6 \mathrm{Ma}$ (Fig. F8). Throughout the Pliocene and Quaternary, the long-term trends of opal depositional rates at Sites 1095, 1096, and 1101 exhibit a much better correspondence than $\mathrm{MAR}_{\text {opal }}$ (Figs. F4, F8). Highest opal depositional rates (45 to $60 \mathrm{~g} / \mathrm{m}^{2}$ per yr) occurred between 5.2 and 3.1 Ma at Sites 1095 and 1096. Today, comparable opal depositional rates are reported from the Scotia Sea, south of the Polar Front, and from the eastern ACC (Schlüter et al., 1998). During the Quaternary, opal depositional rates in the Bellingshausen Sea varied between $20 \mathrm{~g} / \mathrm{m}^{2}$ per yr at Site 1095 and $11 \mathrm{~g} / \mathrm{m}^{2}$ per yr at Site 1096. For comparison, on the continental margin in the Weddell Sea, between 18 and $30 \mathrm{~g} / \mathrm{m}^{2}$ per yr opal are deposited during the present interglacial (Schlüter et al., 1998). In general, the long-term patterns of the estimated opal depositional rates at Sites 1095, 1096, and 1101 reflect those of the opal contents (Fig. F3). This finding suggests that the opal concentrations represent a more reliable proxy for paleoproductivity than the $\mathrm{MAR}_{\text {opal }}$ in the drift setting of the Bellingshausen Sea.

\section{Paleoproductivity Changes in the Bellingshausen Sea since the Late Miocene-Paleoceanographic and Paleoclimatological Impacts}

Biological productivity in the surface waters of the polar Southern Ocean is mainly controlled by the availability of light, which is controlled by sea-ice cover. In general, (sub-)polar conditions seem to have prevailed in the Bellingshausen Sea throughout the Neogene and Quaternary. The microfossil assemblages found in the drift sediments at Sites 1095, 1096, and 1101 show no evidence of significantly warmer surface-water temperatures than today, even though the occurrence of particular diatom species and calcareous nannofossils in some intervals might indicate a more subantarctic setting (Barker, Camerlenghi, Acton, et al., 1999; M. Iwai, pers. comm., 1999). Therefore, we assume that seaice coverage was the main factor in limiting paleoproductivity. At present, the duration of sea-ice coverage in the Bellingshausen Sea is 
controlled by atmospheric heat supply and by upwelling of warm CDW (Hofmann et al., 1996; Jacobs and Comiso, 1997).

We expect past changes in sea-ice coverage to have been linked to regional climate in the Antarctic Peninsula area, which should have influenced the air temperatures, the upwelling rate of CDW, and/or the geographic position of the Polar Front. Another global aspect concerns the heat budget of the CDW, which depends on interhemispheric thermohaline circulation, particularly on the contribution of deep waters from northern hemispheric sources to the Southern Ocean. The heat transfer by this Northern Component Water (NCW) may have influenced sea-ice extent in the Bellingshausen Sea. Of course, we expect both positive and negative feedbacks between regional climate and global thermohaline circulation, raising "chicken and egg problems." For example, regional warming in Antarctica and the adjacent Southern Ocean might trigger a southward shift of the ACC, resulting in enhanced upwelling and a stronger thermohaline overturn, which might cause more inflow of NCW (Toggweiler and Samuels, 1995; Billups et al., 1998; Kim and Crowley, 2000). In turn, heating of the Southern Ocean by NCW injection might result in higher precipitation and, thus, ice buildup in Antarctica, leading to regional cooling (Prentice and Matthews, 1991; Billups et al., 1998). Moreover, the waxing and waning of sea-ice coverage in the Southern Ocean is expected to influence global climate via the atmosphere. Sea-ice expansion not only enhances the global albedo, but also reduces the atmospheric $\mathrm{CO}_{2}$ level because sea-ice coverage restricts $\mathrm{CO}_{2}$ release from the ocean to the atmosphere (Hanna, 1996; Elderfield and Rickaby, 2000).

\section{Late Miocene (9.5-5.23 Ma)}

The occurrence of IRD in upper Miocene sediments from the Bellingshausen Sea recovered at Site 1095, ODP Leg 178 (Barker, Camerlenghi, Acton, et al., 1999) and at Site 325, Deep Sea Drilling Project Leg 35 (Hollister, Craddock, et al., 1976), as well as clay mineralogical and sedimentological evidence from continental margin deposits recovered in the Weddell Sea during ODP Leg 113 (Kennett and Barker, 1990), suggest that major cooling and glaciation had affected the Antarctic Peninsula region at least since the early late Miocene. A major eustatic sea level drop during the middle Miocene coinciding with a significant increase in global ice-volume (Lear et al., 2000) was interpreted to indicate ice sheet buildup in West Antarctica at 15 Ma (Abreu and Anderson, 1998). At $\sim 10$ Ma the production of NCW similar to modern NADW had started in the North Atlantic (Woodruff and Savin, 1989; Wright et al., 1991; King et al., 1997). Concomitantly, opal sedimentation in the Southern Ocean, comparable to the present situation, became widespread (Ciesielski and Weaver, 1983; Wise et al., 1985). As indicated by oxygen isotope data measured on benthic and planktonic foraminifers in the subantarctic South Atlantic, relatively warm and stable oceanographic conditions prevailed in the Southern Ocean between $\sim 11$ and 6.6 Ma (Müller et al., 1991; Warnke et al., 1992).

The estimated opal depositional rates at Site 1095 were generally higher during the late Miocene than during the late Quaternary (Figs. F8, F9), suggesting reduced sea-ice coverage in the Bellingshausen Sea. The flow of NCW was well established but weaker than present (King et al., 1997). Therefore, we conclude that regional climate was warmer than during the Quaternary and was mainly responsible for higher productivity offshore from the Antarctic Peninsula.
F9. Estimated opal depositional rates, p. 31 .

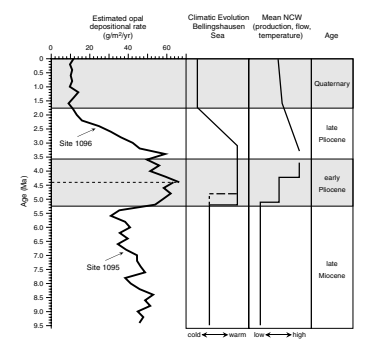




\section{C.-D. HILLENBRAND AND D.K. FÜTTERER

Based on low-resolution benthic $\delta^{13} \mathrm{C}$ records, Wright et al. (1991) and Wright and Miller (1996) reported distinct long-term changes in the NCW flow to the Southern Ocean throughout the late Miocene. We do not recognize possible effects of such circulation changes at Site 1095 because the relative minima of opal depositional rates centered at $\sim 7.8, \sim 6.6$, and $\sim 5.6 \mathrm{Ma}$ (Figs. F8, F9) are not synchronous with the supposed changes in NCW flow and might therefore also represent consequences of regional climatic trends. High-resolution records of carbonate fluxes at the Ceara Rise in the equatorial West Atlantic, however, indicate a more uniform NCW flow (King et al., 1997), which would be consistent with the opal record in the Bellingshausen Sea. We consider that the minimum of opal deposition recorded at $~ 5.6$ Ma may be linked to the Messinian Event, when the Mediterranean Sea had desiccated (Krijgsman et al., 2000). Because Mediterranean Overflow Water (MOW) is supposed to act as an important source water for the formation of deep water in the Nowegian-Greenland Sea (Reid, 1979), the cessation of MOW outflow during the Messinian stage likely caused strong decrease in NCW production (e.g., Woodruff and Savin, 1989; Müller et al., 1991). A concomitant reduction of heat injection into the CDW during the Messinian stage may have triggered enhanced sea-ice coverage and low productivity in the Bellingshausen Sea, but stratigraphy is uncertain for this period of time at Site 1095.

\section{Early Pliocene (5.23-3.58 Ma)}

During the early Pliocene, the climate over Antarctica and the adjacent Southern Ocean was warmer than today (e.g., Abelmann et al., 1990; Hodell and Venz, 1992; Barker, 1995; Burckle et al., 1996; Barker et al., 1999). In the deep western equatorial Atlantic, a significant lowering of the calcite-lysocline at 5.1 Ma is interpreted to indicate the onset of a strengthened southward NCW flow analogous to modern NADW flow (King et al., 1997). Additionally, vertical gradients in benthic foraminiferal $\delta^{18} \mathrm{O}$ from that area showed the NCW to be slightly warmer than present-day NADW between 4.2 and 3.7 Ma (Billups et al., 1998). Foraminiferal oxygen isotope data and high carbonate accumulation in the subantarctic South Atlantic (Müller et al., 1991; Froelich et al., 1991; Hodell and Venz, 1992), as well as siliceous microfossil assemblages in the Weddell Sea (Abelmann et al., 1990) indicate elevated surface water temperatures prevailing in the Southern Ocean, at least during particular early Pliocene time intervals. These findings agree with a paleoceanographic scenario suggested by Berger and Wefer (1996), which assumes a stronger thermohaline deep-water circulation in the Atlantic Ocean with maximum formation and convection of NCW during the early Pliocene in response to the closure of the Panama Isthmus.

Throughout the early Pliocene, the opal depositional rates at Sites 1095 and 1096 were much higher than during the late Quaternary (Figs. F8, F9), pointing to a strong reduction in annual sea-ice extent or even open ocean conditions in the Bellingshausen Sea. We consider, however, that also during that time interval short-term advances of ice masses across the Antarctic Peninsula shelf occurred, as documented by clay mineral fluctuations at Sites 1095 and 1096 (Hillenbrand and Ehrmann, Chap. 8, this volume) and by glacial unconformities on the shelf (Bart, 2001). Nevertheless, a general early Pliocene warming in the Bellingshausen Sea agrees well with both warm atmospheric conditions over Antarctica and with an intensification of meridional heat transfer 


\section{C.-D. HILLENBRAND AND D.K. FÜTTERER NeOgene TO QUATERnARY OPAL Deposition}

into the Southern Ocean due to enhanced thermohaline circulation in the Atlantic Ocean.

A crucial point, however, is the exact timing of the climate change. The estimated opal depositional rates at Site 1095 exceeded the mean late Miocene level already at $~ 5.2 \mathrm{Ma}$ (Figs. F8, F9), synchronously with strengthened NCW flow recorded at the Ceara Rise (King et al., 1997). Considering the possible hiatus spanning the time interval between 6.1 and 5.0 Ma at Site 1095, the early Pliocene opal depositional rates would have reached maximum values at $\sim 4.8 \mathrm{Ma}$. In both cases, the increase of productivity in the Bellingshausen Sea precedes the closure of the Panama Isthmus starting, at 4.6 Ma (Haug and Tiedemann, 1998). Moreover, Warnke et al. (1992) reported particular warm conditions to have dominated in the subantarctic South Atlantic between 5.2 and 4.6 Ma. Thus, we conclude an early onset of Pliocene warming in the Antarctic realm, which might have enabled an intensification of thermohaline deep-water circulation in the Atlantic Ocean at $\sim 5$ Ma via a positive feedback mechanism, as suggested by Toggweiler and Samuels (1995) and Kim and Crowley (2000). On the other hand, the formation of NCW, which was warmer and more saline than present NADW, took place at 4.2 Ma (Billups et al., 1998) and might therefore be caused exclusively by the closure of the Panama Seaways (Berger and Wefer, 1996).

\section{Late Pliocene (3.58-1.77 Ma)}

Intense cooling of the Northern Hemisphere started at $3.2 \mathrm{Ma}$ and triggered a stepwise decrease in glacial NCW production, probably due to enhanced sea-ice formation in the Nordic Seas (e.g., Raymo et al., 1990, 1992; Berger and Wefer, 1996; Wright and Miller, 1996). Enhanced glacial carbonate dissolution recorded in the deep western equatorial Atlantic also reflects the decrease in NCW flux in response to the northward expansion of southern source deep waters between 3.3 and 2.6 Ma (Tiedemann and Franz, 1997). During that time interval, significant cooling affected the Atlantic Sector of the Southern Ocean, as indicated by a decrease of surface- and bottom-water temperatures, a northward shift of the Polar Frontal Zone, expansion of perennial seaice coverage, and decreasing ventilation rates in the deep waters caused by reduced NCW injection into the CDW at $\sim 2.8 \mathrm{Ma}$ (Kennett and Barker, 1990; Abelmann et al., 1990; Hodell and Warnke, 1991; Hodell and Venz, 1992; Warnke et al., 1992). It was speculated that with the onset of northern hemisphere glaciation, the Antarctic continent was affected by an episode of major cooling in combination with increased ice buildup (Kennett and Barker, 1990).

Late Pliocene opal depositional rates at Sites 1095, 1096, and 1101 did not decrease significantly until $\sim 3.1 \mathrm{Ma}$ (Fig. F8). Since that time, biological productivity in the Bellingshausen Sea declined continuously toward the Pliocene-Pleistocene transition (Figs. F8, F9). The decrease in NCW formation and flow throughout the late Pliocene likely caused the annual sea-ice coverage in the Bellingshausen Sea to expand, thus reducing opal depositional rates. Intensification of deep- and bottomwater circulation at the same time may have resulted in nondeposition or sediment erosion near the Matuyama/Gauss boundary at Site 1095. A similar scenario was suggested to explain a hiatus between 2.7 and 2.4 Ma on the Meteor Rise in the subantarctic South Atlantic (Hodell and Venz, 1992). 


\section{C.-D. HILLENBRAND AND D.K. FÜTTERER

During the Pliocene and Quaternary, sedimentation rates at Site 1095 on the distal flank of Drift 7 were generally much lower than at Site 1096 near the crest (Fig. F4), suggesting that at Site 1095 the bottomcurrents around the drift held more particles in suspension than at Site 1096. Therefore, a stronger bottom-current flow on the Antarctic Peninsula continental rise, possibly induced by enhanced WSDW formation in the Weddell Sea, would interrupt deposition or remove sediments at Site 1095 rather than at Site 1096.

\section{Quaternary (1.77-0 Ma)}

Benthic $\delta^{13} \mathrm{C}$ records in the North Atlantic and in the western equatorial Atlantic were interpreted to reflect a significantly reduced NADW flow during the Quaternary glacials compared to the late Pliocene (Raymo et al., 1990; Bickert et al., 1997). In the Atlantic sector of the Southern Ocean, early Quaternary climatic conditions were found to be warmer than at present (e.g., Abelmann et al., 1990; Hodell and Venz, 1992). Distinct glacial-interglacial cyclicity, which was superimposed on a general cooler climate with widespread occurrence of sea ice (Abelmann et al., 1990), characterized the late Quaternary Southern Ocean (e.g., Charles et al., 1991; Grobe and Mackensen, 1992; Howard and Prell, 1994; Hodell et al., 2000).

The long-term trend of opal depositional rates recorded at Sites 1095, 1096, and 1101 shows no significant changes of biological productivity in the Bellingshausen Sea throughout the Quaternary (Figs. F8, F9). However, mean NADW contribution to the Southern Ocean should have rather weakened during that time interval because of the stronger suppression during glacials. Therefore, we conclude that the observed constant level in productivity may be related to relatively stable climatic conditions in the Antarctic Peninsula area. In the Bellingshausen Sea, distinct short-term fluctuations of productivity linked to orbitalforced glacial-interglacial cyclicity on Milankovitch timescales are documented at least for the late Quaternary (e.g., at gravity core site PS1565) (Figs. F5, F6) (Pudsey and Camerlenghi, 1998; Hillenbrand, 2000; Pudsey, 2000).

\section{CONCLUSIONS}

The records of opal contents and opal accumulation rates in drift sediments on the continental rise west of the Antarctic Peninsula provide signals of paleoproductivity; even then the opal records are overprinted by dissolution in the water column and the sediment column and by bottom current-induced lateral sediment supply (focusing). Previously reported positive correlations between opal and biogenic barium records in upper Quaternary sedimentary sequences suggest that the primary signal of opal deposition is not masked crucially by dissolution processes and that opal records represent a more suitable proxy for paleoproductivity rather than $\mathrm{TOC}$ and $\mathrm{CaCO}_{3}$ records.

Opal contents at ODP Leg 178 Sites 1095, 1096, and 1101 show similar long-term trends throughout the Neogene and Quaternary but are affected by dilution with lithogenic matter. In contrast, the opal accumulation rates that reflect deposition and preservation of opal exhibit marked discrepancies between the sites. Because the influence of bottom current-delivered biosiliceous particles on the opal accumulation rates is assumed not to be crucial at the drift sites, the main cause for 


\section{C.-D. HILLENBRAND AND D.K. FÜTTERER NeOgene TO QUATERnARY OPAL Deposition}

the discrepancies in opal accumulation is seen in locally different opal preservation linked to local variations of bottom current-induced lateral supply of lithogenic detritus. These variations are clearly expressed in local variability of sedimentation rates. A correlation between sedimentation rate and opal preservation found for continental margin deposits in the Ross Sea, which represents an environmental and depositional setting comparable to that in the Bellingshausen Sea, can be applied to decipher the signal of original opal deposition on the seafloor in the Bellingshausen Sea from the opal accumulation in the drift deposits. On long-term timescales, the reconstructed opal depositional rates show patterns similar to those of the opal contents and a much better coherency between the different locations on the Antarctic Peninsula continental rise.

Supposing that sea-ice coverage within the Antarctic Zone was the main factor controlling biological productivity in the Bellingshausen Sea, and thus the estimated opal depositional rates on the continental rise, we reconstructed paleoceanographic long-term changes during the Neogene and Quaternary considering the climatic control on regional and on global scales. During the late Miocene, temperatures in the Bellingshausen Sea as well as in the Atlantic sector of the Southern Ocean were slightly warmer than at present. Because heat injection by northern source deep-water masses was reduced during that time, regional Antarctic climate was more important for paleoproductivity than global deep-water circulation.

Higher productivity was reconstructed for the early Pliocene and early late Pliocene (to $\sim 3.1 \mathrm{Ma}$ ) than during the late Miocene. A strong productivity increase in the Bellingshausen Sea before the closure of the Panama Isthmus might indicate that initial strengthening in NCW flow reported at $\sim 5 \mathrm{Ma}$ was at least partly triggered by early warming in Antarctica and the adjacent Southern Ocean. A positive linkage between Antarctic climate and NCW input is assumed for maintaining the Pliocene warm period, when sea-ice coverage in the Bellingshausen Sea was strongly reduced, if not absent. Productivity in the Bellingshausen Sea decreased between 3.1 and $1.8 \mathrm{Ma}$, indicating expansion of annual sea-ice coverage. This climatic deterioration probably was caused by the reduction of NADW inflow due to increased glaciation in the Northern Hemisphere. We interpret the relatively constant level of productivity during the Quaternary as a consequence of stable climatic conditions in the Antarctic Peninsula area.

\section{ACKNOWLEDGMENTS}

We thank the crew and shipboard scientific party of ODP Leg 178 for sampling and making this study possible, and we are indebted to T.C.W. Wolf-Welling for providing additional samples. We wish to thank M. Minning and T. Koschnik for sample preparation. We appreciate helpful discussions with P.F. Barker, B. Diekmann, H. Grobe, A. Nimmergut, C. Pudsey, M. Rebesco, J. Schuffert, and R. Usbeck. Our paper benefited from the constructive reviews by A. Camerlenghi, E. Koning, and by an anonymous reviewer.

This research used samples and/or data provided by the Ocean Drilling Program (ODP). ODP is sponsored by the U.S. National Science Foundation (NSF) and participating countries under management of Joint Oceanographic Institutions (JOI), Inc. Funding for this research was provided by the Deutsche Forschungsgemeinschaft (FU119/21-1). 


\section{REFERENCES}

Abelmann, A., Gersonde, R., and Spiess, V., 1990. Pliocene-Pleistocene paleoceanography in the Weddell Sea: siliceous microfossil evidence. In Bleil, U., and Thiede, J. (Eds.), Geologic History of the Polar Oceans: Arctic Versus Antarctic: NATO ASI Ser., Ser. C, 308:729-759.

Abreu, V.S., and Anderson, J.B., 1998. Glacial eustasy during the Cenozoic: sequence stratigraphic implications. AAPG Bull., 82:1385-1400.

Archer, D., Lyle, M., Rodgers, K., and Froelich, P., 1993. What controls opal preservation in tropical deep-sea sediments? Paleoceanography, 8:7-21.

Barker, P.F., 1995. The proximal marine sediment record of Antarctic climate since the late Miocene. In Cooper, A.K., Barker, P.F., and Brancolini G. (Eds.), Geology and Seismic Stratigraphy of the Antarctic Margin. Am. Geophys. Union, Antarct. Res. Ser., 68:25-57.

Barker, P.F., Barrett, P.J., Cooper, A.K., and Huybrechts, P., 1999. Antarctic glacial history from numerical models and continental margin sediments. Palaeogeogr., Palaeoclimatol., Palaeoecol., 150:247-267.

Barker, P.F., Camerlenghi, A., Acton, G.D., et al., 1999. Proc. ODP, Init. Repts., 178 [CDROM]. Available from: Ocean Drilling Program, Texas A\&M University, College Station, TX 77845-9547, U.S.A.

Bart, P.J., 2001. Did the Antarctic ice sheets expand during the early Pliocene? Geology, 29: 67-70.

Berger, W.H., and Wefer, G., 1996. Expeditions into the past: paleoceanographic studies in the South Atlantic. In Wefer, G., Berger, W.H., Siedler, G., Webb, D.J. (Eds.), The South Atlantic: Present and Past Circulation: Berlin (Springer-Verlag), 363-410.

Berggren, W.A., Kent, D.V., Swisher, C.C., III, and Aubry, M.-P., 1995. A revised Cenozoic geochronology and chronostratigraphy. In Berggren, W.A., Kent, D.V., Aubry, M.-P., and Hardenbol, J. (Eds.), Geochronology, Time Scales and Global Stratigraphic Correlation. Spec. Publ.-Soc. Econ. Paleontol. Mineral. (Soc. Sediment. Geol.), 54:129-212.

Bickert, T., Curry, W.B., and Wefer, G., 1997. Late Pliocene to Holocene (2.6-0 Ma) western equatorial Atlantic deep-water circulation: inferences from benthic stable isotopes. In Shackleton, N.J., Curry, W.B., Richter, C., and Bralower, T.J. (Eds.), Proc. ODP, Sci. Results, 154: College Station, TX (Ocean Drilling Program), 239-253.

Billups, K., Ravelo, A.C., and Zachos, J.C., 1998. Early Pliocene deep water circulation in the western equatorial Atlantic: implications for high-latitude climate change. Paleoceanography, 13:84-95.

Bonn, W.J., Gingele, F.X., Grobe, H., Mackensen, A., and Fütterer, D.K., 1998. Palaeoproductivity at the Antarctic continental margin: opal and barium records for the last 400 ka. Palaeogeogr., Palaeoclimat., Palaeoecol., 139:195-211.

Burckle, L.H., Mortlock, R., and Rudolph, S., 1996. No evidence for extreme, long term warming in early Pliocene sediments of the Southern Ocean. Mar. Micropaleontol., 27:215-226.

Camerlenghi, A., Crise, A., Pudsey, C.J., Accerboni, E., Laterza, R., and Rebesco, M., 1997. Ten-month observation of the bottom current regime across a sediment drift of the Pacific margin of the Antarctic Peninsula. Antarct. Sci., 9:426-433.

Camerlenghi, A., Volpi, V., Rebesco, M., Hillenbrand, C.-D., and Moerz, T., 2001. Deep sea sediment consolidation through the glacial history of the Pacific margin of the Antarctic Peninsula. In Florindo, F., and Copper, A.K. (Eds.), The Geological Record of the Antarctic Ice Sheet from Drilling, Coring and Seismic Studies. Quaderni di Geofisica, 16:31-32.

Ceccaroni, L., Frank, M., Frignani, M., Langone, L., Ravaioli, M., and Mangini, A., 1998. Late Quaternary fluctuations of biogenic component fluxes on the continental slope of the Ross Sea, Antarctica. J. Mar. Systems, 17:515-525. 
Charles, C.D, Froelich, P.N., Zibello, M.A., Mortlock, R.A., and Morley, J.J., 1991. Biogenic opal in southern ocean sediments over the last 450,000 years: implications for surface water chemistry and circulation. Paleoceanography, 6:697-728.

Chernaykova, A.M., and Stunzhas, P.A., 1998. Hydrochemical structure of the waters in the Pacific sector of the Antarctic. Oceanology, 38:333-341.

Ciesielski, P.F., and Weaver, F.M., 1983. Neogene and Quaternary paleoenvironmental history of Deep Sea Drilling Project Leg 71 sediments, southwest Atlantic Ocean. In Ludwig, W.J., Krasheninnikov, V.A., et al., Init. Repts. DSDP, 71 (Pt. 1): Washington (U.S. Govt. Printing Office), 461-477.

CLIMAP Project Members, 1981. Seasonal reconstructions of the Earth's surface at the last glacial maximum. Geol. Soc. Am., Map and Chart Ser., MC36.

Conley, D.J., 1998. An interlaboratory comparison for the measurement of biogenic silica in sediments. Mar. Chem., 63:39-48.

DeMaster, D.J., 1981. The supply and accumulation of silica in the marine environment. Geochim. Cosmochim. Acta, 45:1715-1732.

DeMaster, D.J., Ragueneau, O., and Nittrouer, C.A., 1996. Preservation efficiences and accumulation rates for biogenic silica and organic C, N, and P in high-latitude sediments: the Ross Sea. J. Geophys. Res., 101:18501-18518.

Denton, G.H., 2000. Does an asymmetric thermohaline-ice-sheet oscillator drive 100,000-yr glacial cycles? J. Quat. Sci., 15:301-318.

Elderfield, H., and Rickaby, R.E.M., 2000. Oceanic Cd/P ratio and nutrient utilization in the glacial Southern Ocean. Nature, 405:305-310.

Francois, R., Altabet, M.A., Yu, E.-F., Sigman, D.M., Bacon, M.P., Frank, M., Bohrmann, G., Bareille, G., and Labeyrie, L.D., 1997. Contribution of Southern Ocean surface-water stratification to low atmospheric $\mathrm{CO}_{2}$ concentrations during the last glacial period. Nature, 389:929-935.

Frank, M., Eisenhauer, A., Bonn, W.J., Walter, P., Grobe, H., Kubik, P.W., Dittrich-Hannen, B., and Mangini, A., 1995. Sediment redistribution versus paleoproductivity change: Weddell Sea margin sediment stratigraphy and biogenic particle flux of the last 250,000 years deduced from ${ }^{230} \mathrm{Thex},{ }^{10} \mathrm{Be}$ and biogenic barium profiles. Earth Planet. Sci. Lett., 136:559-573.

Frank, M., Gersonde, R., Rutgers van der Loeff, M.M., Bohrmann, G., Nürnberg, C.C., Kubik, P.W., Suter, M., and Mangini, A., 2000. Similar glacial and interglacial export bioproductivity in the Atlantic sector of the Southern Ocean: multiproxy evidence and implications for glacial atmospheric $\mathrm{CO}_{2}$. Paleoceanography, 15:642658.

Froelich, P.N., Malone, P.N., Hodell, D.A., Ciesielski, P.F., Warnke, D.A., Westall, F., Hailwood, E.A., Nobes, D.C., Fenner, J., Mienert, J., Mwenifumbo, C.J., and Müller, D.W., 1991. Biogenic opal and carbonate accumulation rates in the subantarctic South Atlantic: the late Neogene of Meteor Rise Site 704. In Ciesielski, P.F., Kristoffersen, Y., et al., Proc. ODP, Sci. Results, 114: College Station, TX (Ocean Drilling Program), 515-550.

Goodell, H.G., 1973. The sediments. In Goodell, H.G., Houtz, R., Ewing, M., Hayes, D., Naini, B., Echols, R.J., Kennett, J.P., and Donahue, J.G. (Eds.), Marine Sediments of the Southern Oceans. Am. Geophys. Union, Antarct. Map Folio Ser., 17: 1-9.

Grobe, H., and Mackensen, A., 1992. Late Quaternary climatic cycles as recorded in sediments from the Antarctic continental margin. In Kennett, J.P., and Warnke, D.A. (Eds.), The Antarctic Paleoenvironment: A Perspective on Global Change (Pt. 1). Am. Geophys. Union, Antarct. Res. Ser., 56:349-376.

Hanna, E., 1996. The role of Antarctic sea-ice in global climate change. Progr. Phys. Geogr., 20:371-401.

Haug, G.H., and Tiedemann, R., 1998. Effect of the formation of the Isthmus of Panama on Atlantic Ocean thermohaline circulation. Nature, 393:673-676.

Hillenbrand, C.-D., 2000. Glaciomarine Sedimentation on the Continental Margins of the Amundsen and Belllingshausen Seas, West Antarctica: Indications for Paleoenvironmen- 
tal Changes during the Quaternary Climatic Cycles: Bremerhaven (Alfred Wegener Institute for Polar and Marine Research).

Hodell, D.A., Charles, C.D., and Nissemann, U.S., 2000. Comparison of interglacial stages in the South Atlantic sector of the southern ocean for the past $450 \mathrm{kyr}$ : implications for Marine Isotope Stage (MIS) 11. Global Planet. Change, 24:7-26.

Hodell, D.A., and Venz, K., 1992. Toward a high-resolution stable isotopic record of the Southern Ocean during the Pliocene-Pleistocene (4.8 to 0.8 Ma). In Kennett, J.P., Warnke, D.A. (Eds.), The Antarctic Paleoenvironment: A Perspective on Global Change (Pt. 1). Am. Geophys. Union, Antarct. Res. Ser., 56:265-310.

Hodell, D.A., and Warnke, D.A., 1991. Climatic evolution of the Southern Ocean during the Pliocene epoch from 4.8 to 2.6 million years ago. Quat. Sci. Rev., 10:205214.

Hofmann, E.E., Klinck, J.M., Lascara, C.M., and Smith, D.A., 1996. Water mass distribution and circulation west of the Antarctic Peninsula and Bransfield Strait. In Ross, R.M, Hofmann, E.E., Quentin, L.B. (Eds.), Foundations for ecological research west of the Antarctic Peninsula. Antarct. Res. Ser., 70:61-80.

Hollister, C.D., Craddock, C., et al., 1976. Init. Repts. DSDP, 35: Washington (U.S. Govt. Printing Office).

Howard, W.R., and Prell, W.L., 1994. Late Quaternary $\mathrm{CaCO}_{3}$ production and preservation in the Southern Ocean: implications for oceanic and atmospheric carbon cycling, Paleoceanography, 9:453-482.

Jacobs, S.S., 1989. Marine controls on modern sedimentation on the Antarctic continental shelf. Mar. Geol., 85:121-153.

Jacobs, S.S., and Comiso, J.C., 1997. Climate variability in the Amundsen and Bellingshausen Seas. J. Climate, 10:697-709.

Kennett, J.P., and Barker, P.F., 1990. Latest Cretaceous to Cenozoic climate and oceanographic developments in the Weddell Sea, Antarctica: an ocean-drilling perspective. In Barker, P.F., Kennett, J.P., et al., Proc. ODP, Sci. Results, 113: College Station, TX (Ocean Drilling Program), 937-960.

Kim, S.-J., and Crowley, T.J., 2000. Increased Pliocene North Atlantic Deep Water: cause or consequence of Pliocene warming? Paleoceanography, 15:451-455.

King, T.A., Ellis, W.G., Jr., Murray, D.W., Shackleton, N.J., and Harris, S., 1997. Miocene evolution of carbonate sedimentation at the Ceara Rise: a multivariate date/proxy approach. In Shackleton, N.J., Curry, W.B., Richter, C., and Bralower, T.J. (Eds.), Proc. ODP, Sci. Results, 154: College Station, TX (Ocean Drilling Program), 349-365.

Krijgsman, W., Hilgen, F.J., Raffi, I., Sierro, F.J, and Wilson, D.S., 2000. Chronology, causes and progressionof the Messinian salinity crisis. Nature, 400:652-655.

Kumar, N., Anderson, R.F., Mortlock, R.A., Froelich, P.N., Kubik, P., Dittrich-Hannen, B., and Suter, M., 1995. Increased biological productivity and export production in the glacial Southern Ocean. Nature, 378:675-680.

Lear, C.H., Elderfield, H., and Wilson, P.A., 2000. Cenozoic deep-sea temperatures and global ice volumes from $\mathrm{Mg} / \mathrm{Ca}$ in benthic foraminiferal calcite. Science, 287:269272.

Müller, D.W., Hodell, D.A., and Ciesielski, P.F., 1991. Late Miocene to earliest Pliocene (9.8-4.5 Ma) Paleoceanography of the subantarctic Southeast Atlantic: stable isotopic, sedimentologic, and microfossil evidence. In Ciesielski, P.F., Kristoffersen, Y., et al., Proc. ODP, Sci. Results, 114: College Station, TX (Ocean Drilling Program), 459474.

Müller, P.J., and Schneider, R., 1993. An automated leaching method for the determination of opal in sediments and particulate matter. Deep-Sea Res., 40:425-444.

Nelson, D.M., DeMaster, D.J., Dunbar, R.B., and Smith, W.O., Jr., 1996. Cycling of organic carbon and biogenic silica in the Southern Ocean: estimates of watercolumn and sedimentary fluxes on the Ross Sea continental shelf. J. Geophys. Res., 101:18519-18532. 
Nelson, D.M., and Gordon, L.I., 1982. Production and pelagic dissolution of biogenic silica in the Southern Ocean. Geochim. Cosmochim. Acta, 46:491-501.

Nowlin, W.D., Jr., and Zenk, W., 1988. Westward bottom currents along the margin of the South Shetland island arc. Deep-Sea Res., 35:269-301.

Orsi, A.H., Johnson, G.C., and Bullister, J.L.,1999. Circulation, mixing, and production of Antarctic bottom water. Progr. Oceanogr., 43:55-109.

Orsi, A.H., Whitworth III, T., and Nowlin, Jr., W.D., 1995. On the meridional extent and fronts of the Antarctic Circumpolar Current. Deep-Sea Res. Part I, 42:641-673.

Paillard, D., Labeyrie, L., and. Yiou, P., 1996. Macintosh program performs time-series analysis. Eos, 77:379.

Parkinson, C.L., 1994. Spatial patterns in the length of the sea ice season in the Southern Ocean, 1979-1986. J. Geophys. Res., 99:16327-16339.

Patterson, S.L., and Whitworth, T., 1990. Physical oceanography. In Glasby, G.P. (Ed.), Antarctic Sector of the Pacific, Elsevier Oceanogr. Ser., 51:55-93.

Pondaven, P., Ragueneau, O., Tréguer, P., Hauvespre, A., Dezileau, L., and Reyss, J.L., 2000. Resolving the "opal paradox" in the Southern Ocean. Nature, 405:168-172.

Prentice, M.L., and Matthews, R.K., 1991. Tertiary ice sheet dynamics: the snow gun hypothesis. J. Geophys. Res., 96:6811-6827.

Pudsey, C.J., 2000. Sedimentation on the continental rise west of the Antarctic Peninsula over the last three glacial cycles. Mar. Geol., 167:313-338.

Pudsey, C.J., and Camerlenghi, A., 1998. Glacial-interglacial deposition on a sediment drift on the Pacific margin of the Antarctic Peninsula. Antarct. Sci., 10:286308.

Ragueneau, O., Tréguer, P., Leynaert, A., Anderson, R.F., Brzezinski, M.A., DeMaster, D.J., Dugdale, R.C., Dymond, J., Fischer, G., Francois, R., Heinze, C., Maier-Reimer, E., Martin-Jézéquel, V., Nelson, D.M., and Quéguiner, B., 2000. A review of the Si cycle in the modern ocean: recent progress and missing gaps in the application of biogenic ipal as a paleoproductivity proxy. Global Planet. Change, 26:317-365.

Raymo, M.E., Hodell, D., and Jansen, E., 1992. Response of deep ocean circulation to initiation of Northern Hemisphere glaciation (3-2 Ma). Paleoceanography, 7:645672.

Raymo, M.E., Ruddiman, W.F., Shackleton, N.J., and Oppo, D.W., 1990. Evolution of Atlantic-Pacific $\delta^{13} \mathrm{C}$ gradients over the last 2.5 m.y. Earth Planet. Sci. Lett., 97:353368.

Rebesco, M., Camerlenghi, A., and Zanolla, C., 1998. Bathymetry and morphogenesis of the continental margin west of the Antarctic Peninsula. Terra Antart., 5:715-728.

Rebesco, M., Larter, R.D., Barker, P.F., Camerlenghi, A., and Vanneste, L.E., 1997. The history of sedimentation on the continental rise west of the Antarctic Peninsula. In Barker, P.F., and Cooper, A.K. (Eds.), Geology and Seismic Stratigraphy of the Antarctic Margin (Pt. 2). Am. Geophys. Union, Antarctic Res. Ser., 71:29-50.

Rebesco, M., Larter, R.D., Camerlenghi, A., and Barker, P.F., 1996. Giant sediment drifts on the continental rise of the Antarctic Peninsula. Geo-Mar. Lett., 16:65-75.

Reid, J.L., 1979. On the contribution of the Mediterranean Sea outflow to the Norwegian-Greenland Sea. Deep-Sea Res. Part A, 26:1199-1223.

Rutgers van der Loeff, M.M., and van Bennekom., A.J., 1989. Weddell Sea contributes little to silicate enrichment in Antarctic bottom water. Deep-Sea Res. Part A, 36:1341-1357.

Schlüter, M., Rutgers van der Loeff, M.M., Holby, O., and Kuhn, G., 1998. Silica cycle in surface sediments of the South Atlantic. Deep-Sea Res. Part I, 45:1085-1109.

Shimmield, G., Derrick, S., Mackensen, A., Grobe, H., and Pudsey, C., 1994. The history of barium, biogenic silica and organic carbon accumulation in the Wedell Sea and Antarctic Ocean over the last 150,000 years. In Zahn, R., Pedersen, T.F., Kaminski, M.A., and Labeyrie, L. (Eds.), Carbon Cycling in the Glacial Ocean: Constraints on the Ocean's Role in Global Change: Quantitative Approaches in Paleoceanography: Heidelberg (Springer), 555-574. 
Sievers, H.A., and Nowlin, Jr., W.D., 1984. The stratification and water masses at Drake Passage. J. Geophys. Res., 89:10489-10514.

Tiedemann, R., and Franz, S.O., 1997. Deep-water circulation, chemistry, and terrigenous sediment supply in the equatorial Atlantic during the Pliocene, 3.3-2.6 Ma and 5-4.5 Ma. In Shackleton, N.J., Curry, W.B., Richter, C., and Bralower, T.J. (Eds.), Proc. ODP, Sci. Results, 154: College Station, TX (Ocean Drilling Program), 299-318.

Toggweiler, J.R., and Samuels, B., 1995. Effect of Drake Passage on the global thermohaline circulation. Deep-Sea Res. Part I, 42:477-500.

van Bennekom, A.J., Berger, G.W., van der Gaast, S.J., and de Vries, R.T.P., 1988. Primary productivity and the silica cycle in the Southern Ocean (Atlantic Sector). Palaeogeogr., Palaeoclimatol., Palaeoecol., 67:19-30.

Warnke, D.A., Allen, C.P., Müller, D.W., Hodell, D.A., and Brunner, C., 1992. Miocene-Pliocene Antarctic glacial evolution: a synthesis of ice-rafted debris, stable isotope, and planktonic foraminiferal indicators, ODP Leg 114. In Kennett, J.P., and Warnke, D.A. (Eds.), The Antarctic Paleoenvironment: A Perspective on Global Change. Am. Geophys. Union, Antarct. Res. Ser., 56:311-325.

Wise, S.W., Gombos, A.M., and Muza, J.P., 1985. Cenozoic evolution of polar water masses, southwest Atlantic Ocean. In Hsü, K.J., and Weissert, H.J. (Eds.), South Atlantic Paleoceanography: Cambridge (Cambridge Univ. Press), 283-324.

Woodruff, F., and Savin, S.M., 1989. Miocene deepwater oceanography. Paleoceanography, 4:87-140.

Wright, J.D., and Miller, K.G., 1996. Control of North Atlantic deep water circulation by the Greenland-Scotland Ridge. Paleoceanography, 11:157-170.

Wright, J.D., Miller, K.G., and Fairbanks, R.G., 1991. Evolution of modern deep water circulation: evidence from the late Miocene Southern Ocean. Paleoceanography, 6:275-290. 


\section{C.-D. Hillenbrand AND D.K. FüTterer NeOgene To QuATERnARY OPAL Deposition}

Figure F1. Bathymetric map of the continental margin west of the Antarctic Peninsula (taken from Rebesco et al., 1998) with locations of ODP Sites 1095, 1096, and 1101 (solid circles) and of gravity core PS1565 (cross). Sea-ice limits in the Bellingshausen Sea are also shown (taken from Pudsey and Camerlenghi, 1998). $\mathrm{SM}=$ seamount.

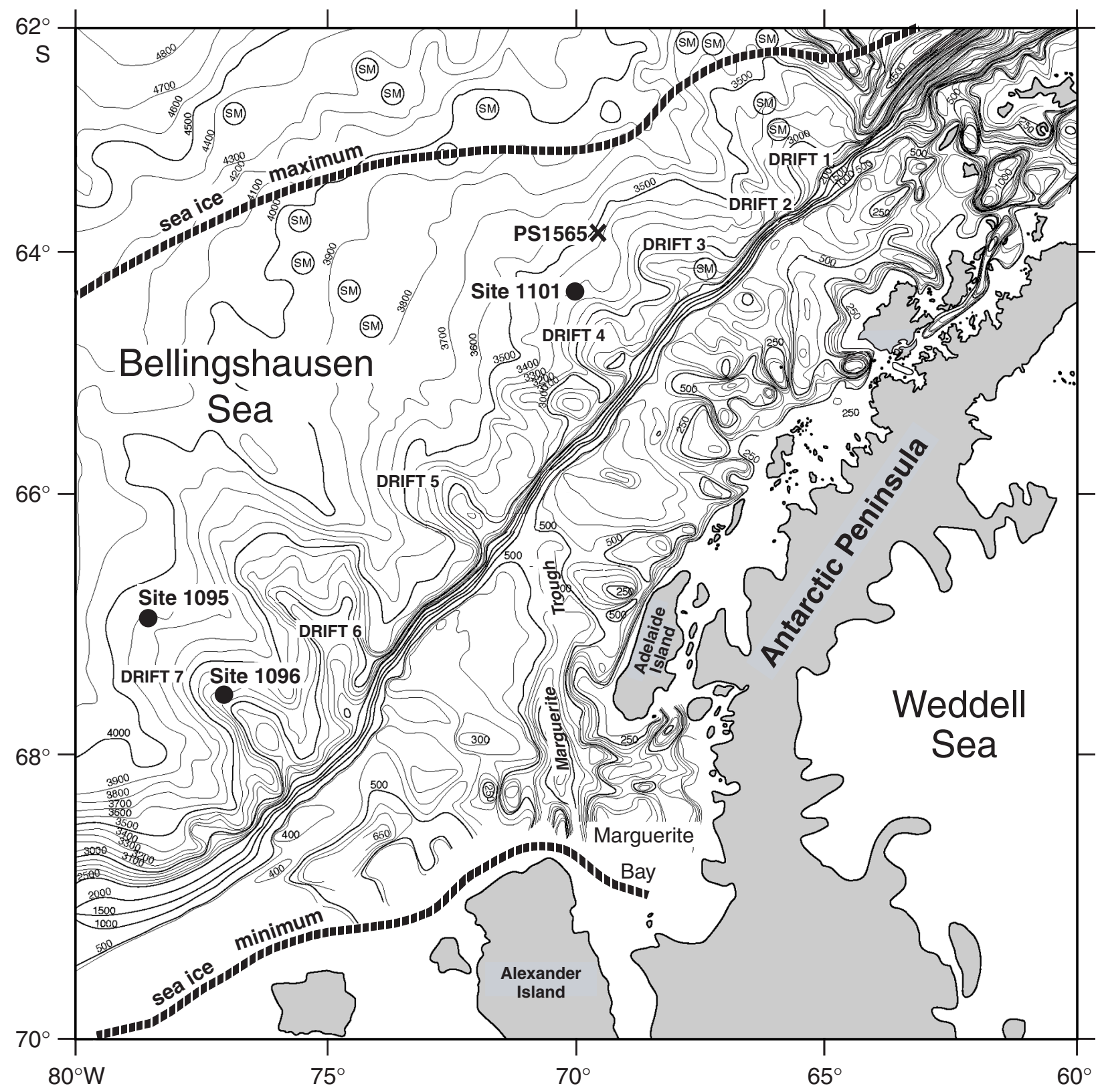


Figure F2. Biogenic opal contents in sediments recovered at Sites 1095, 1096, and 1101. Opal contents are plotted vs. meters composite depth for Sites 1095 and 1096 and vs. recovery corrected meters below seafloor for Site 1101. Ages were taken from Barker, Camerlenghi, Acton, et al. (1999). Stars within the opal curves at Sites 1095 and 1096 mark turbidites.

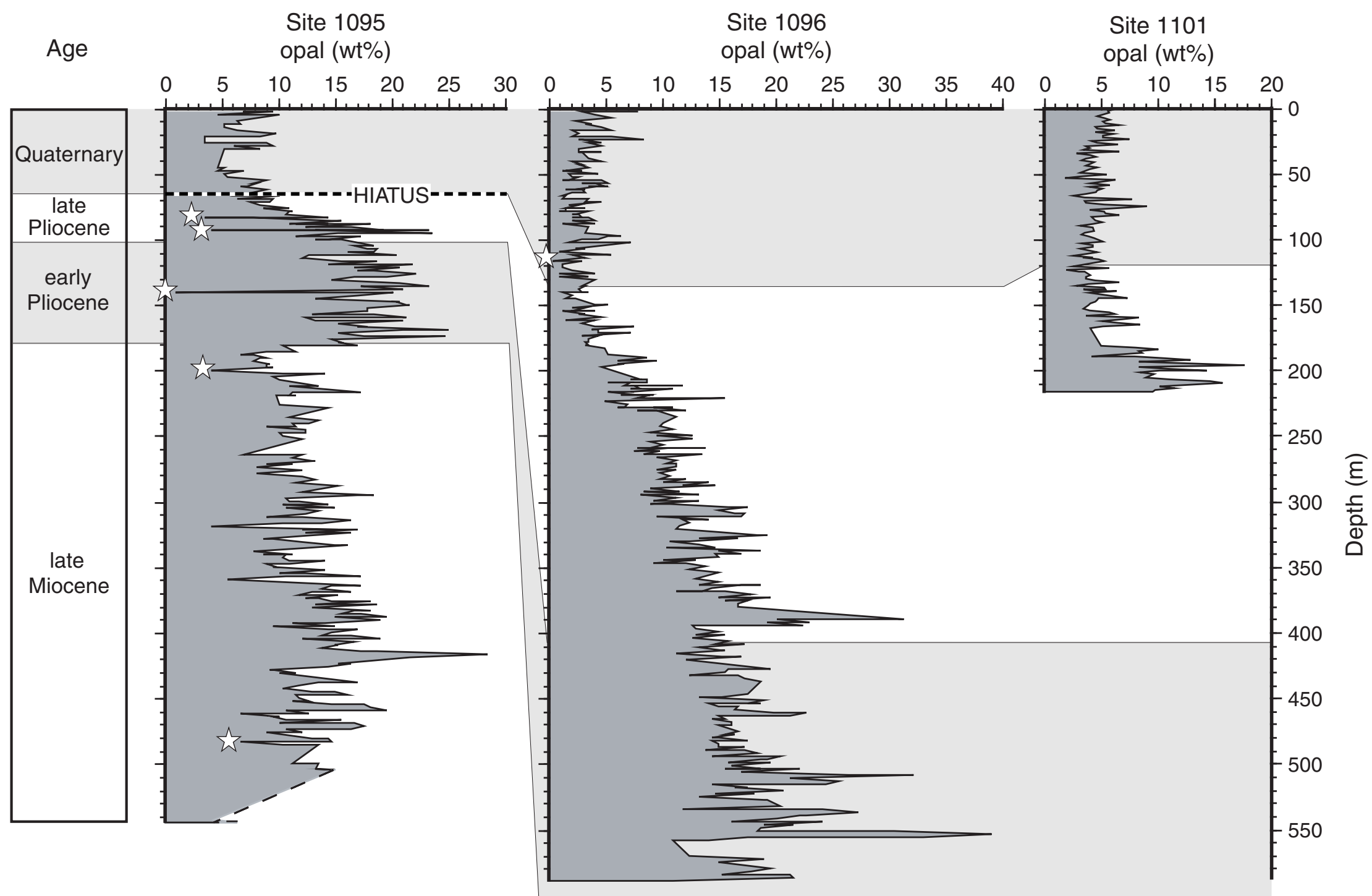


Figure F3. Opal contents (shaded) in sediments recovered at Sites 1095, 1096, and 1101 plotted vs. age. The bold lines depict opal contents linearly integrated at time increments of 200 k.y.

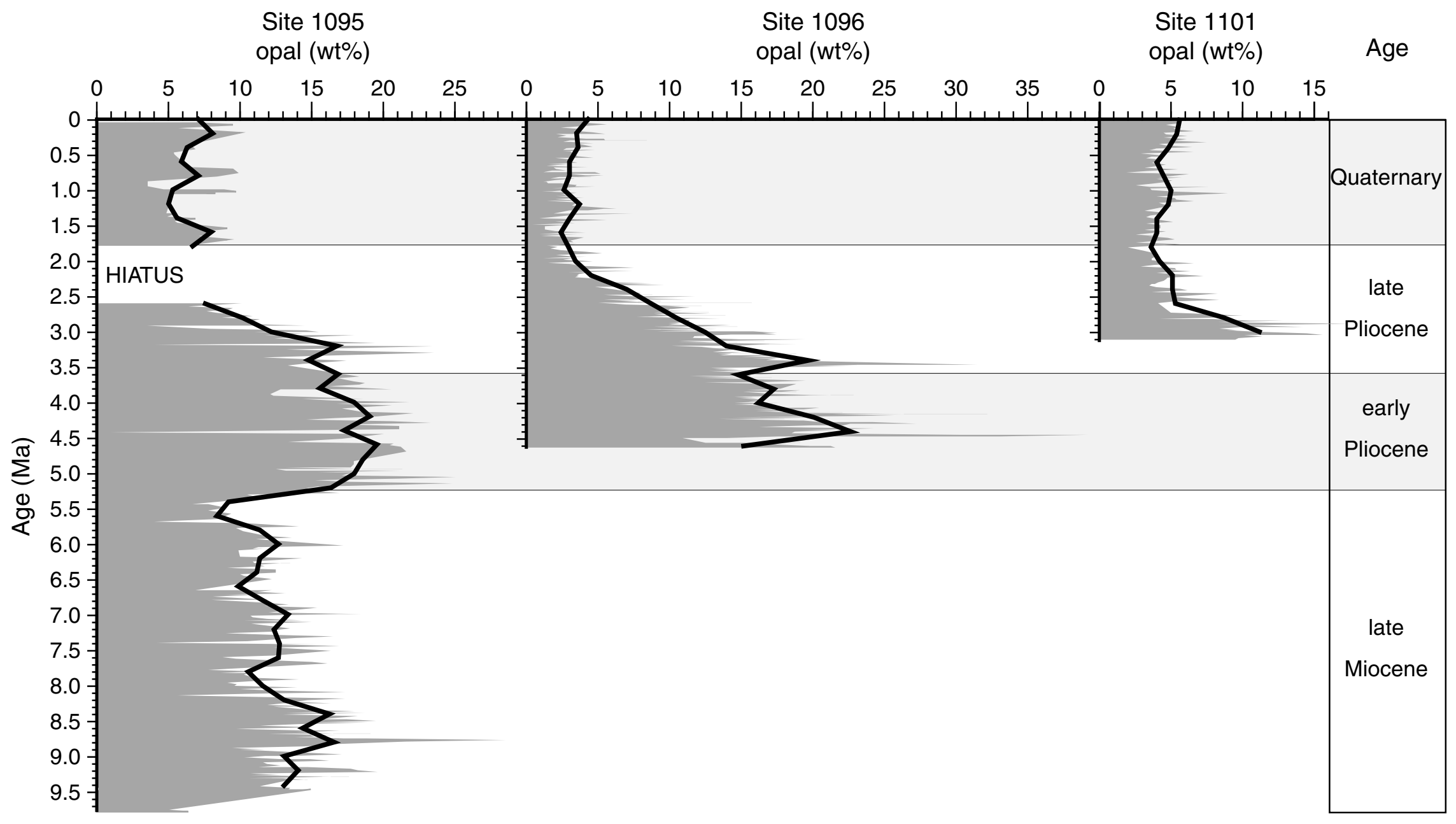


Figure F4. Opal accumulation rates $\left(\mathrm{MAR}_{\text {opal }}\right.$ ) (shaded) and linear sedimentation rates (LSR) (black histogram lines) in sediments recovered at Sites 1095, 1096, and 1101 plotted vs. age.

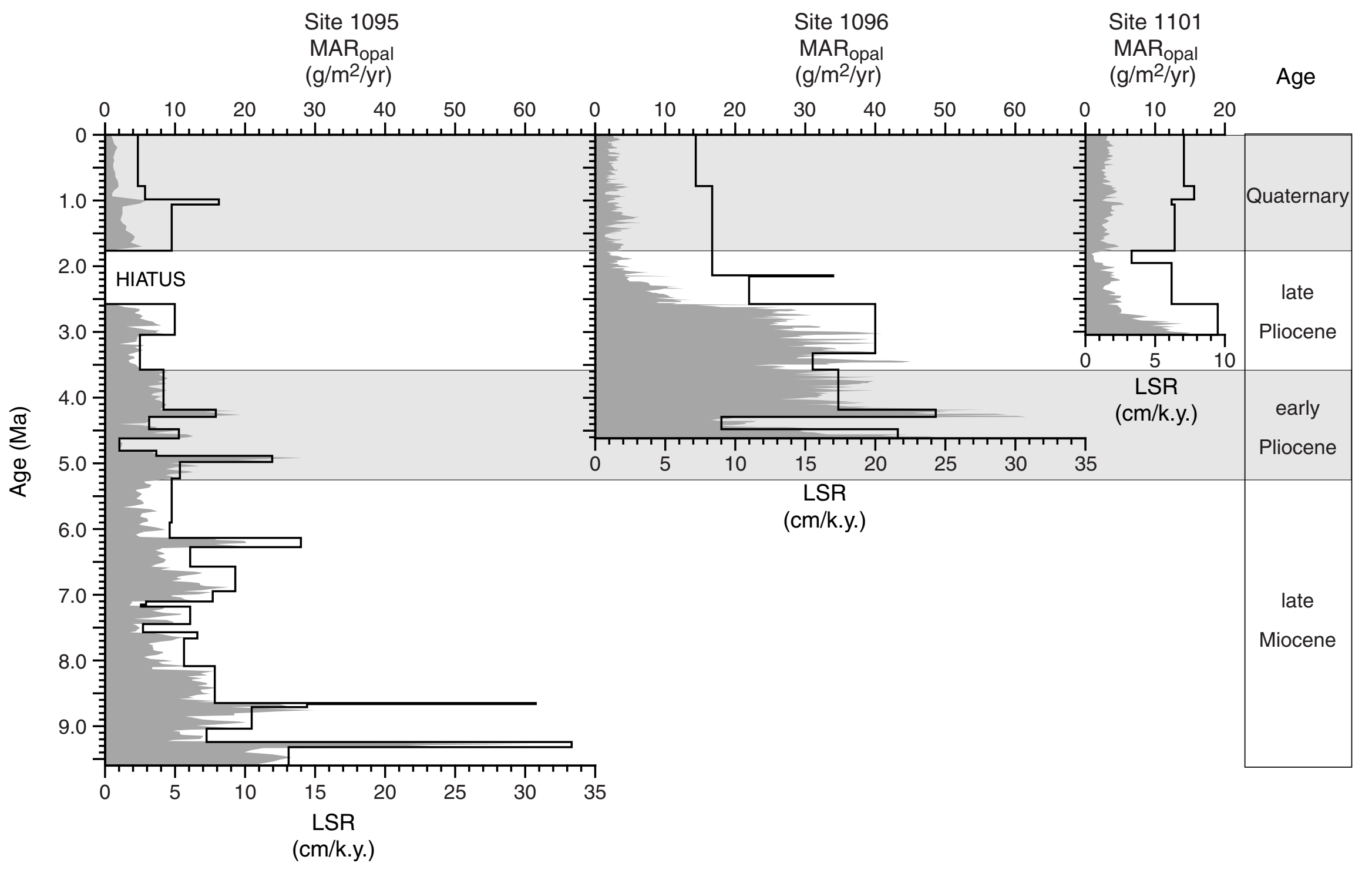


Figure F5. Contents of biogenic opal, total organic carbon (TOC), calcite $\left(\mathrm{CaCO}_{3}\right)$, and biogenic barium $\left(\mathrm{Ba}_{\text {bio }}\right)$ in sediments at gravity core site PS1565 plotted vs. depth (taken from Hillenbrand, 2000). Note that only the maxima in opal contents correlate with the maxima in $\mathrm{Ba}_{\text {bio }}$ concentrations of interglacial marine isotope stages (early Stage 5 as well as Stage 1), whereas TOC and $\mathrm{CaCO}_{3}$ exhibit significant differences.

\section{PS1565}

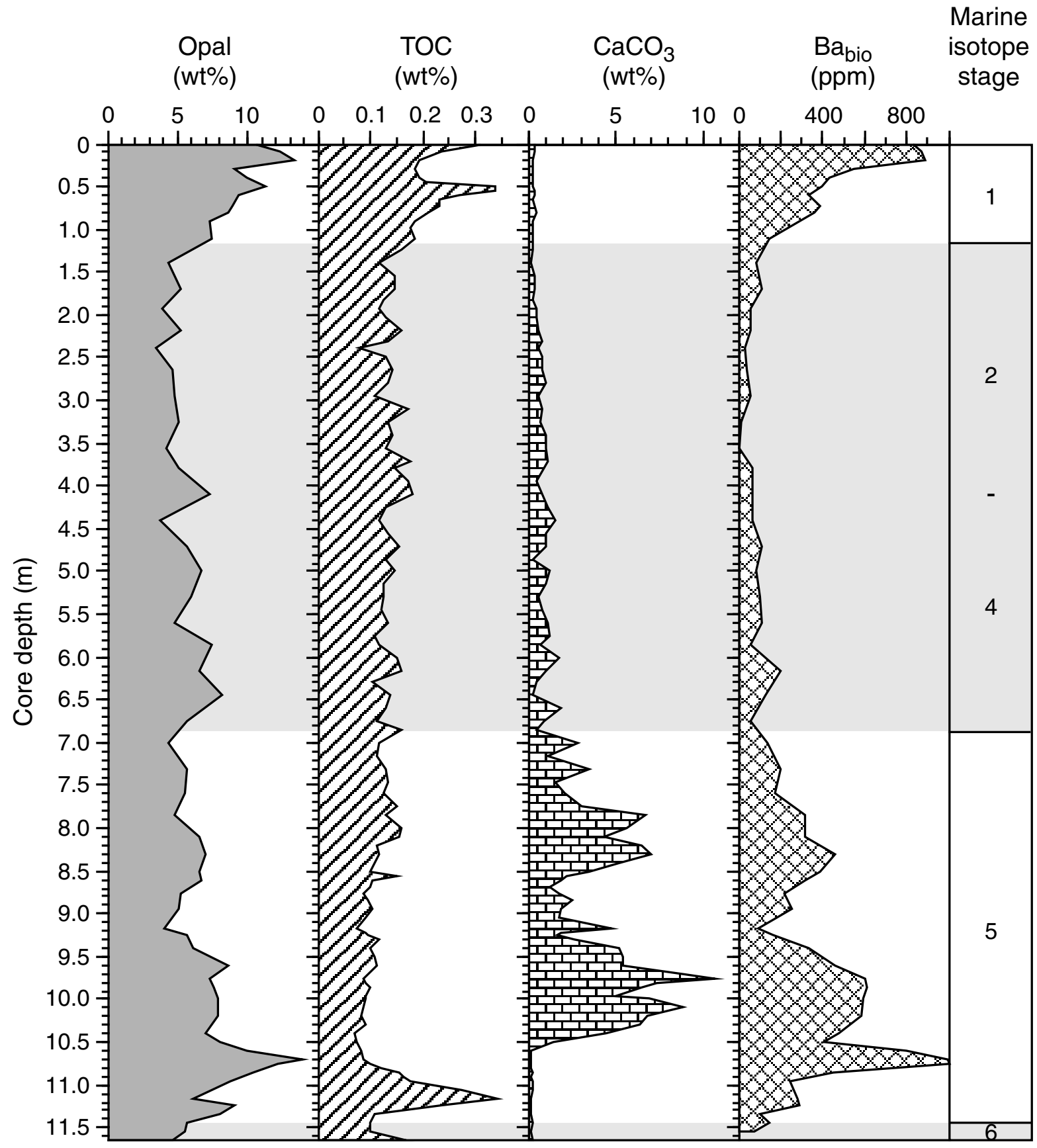


Figure F6. Linear sedimentation rate (LSR) (black histogram line) and accumulation rates of opal (MAR $\mathrm{opal}_{\text {) }}$, total organic carbon $\left(\mathrm{MAR}_{\mathrm{TOC}}\right)$, calcite $\left(\mathrm{MAR}_{\mathrm{CaCO}_{3}}\right)$, and biogenic barium $\left(\mathrm{MAR}_{\mathrm{Ba} \text { bio }}\right)$ in sediments at gravity core site PS1565 plotted vs. age (taken from Hillenbrand, 2000).

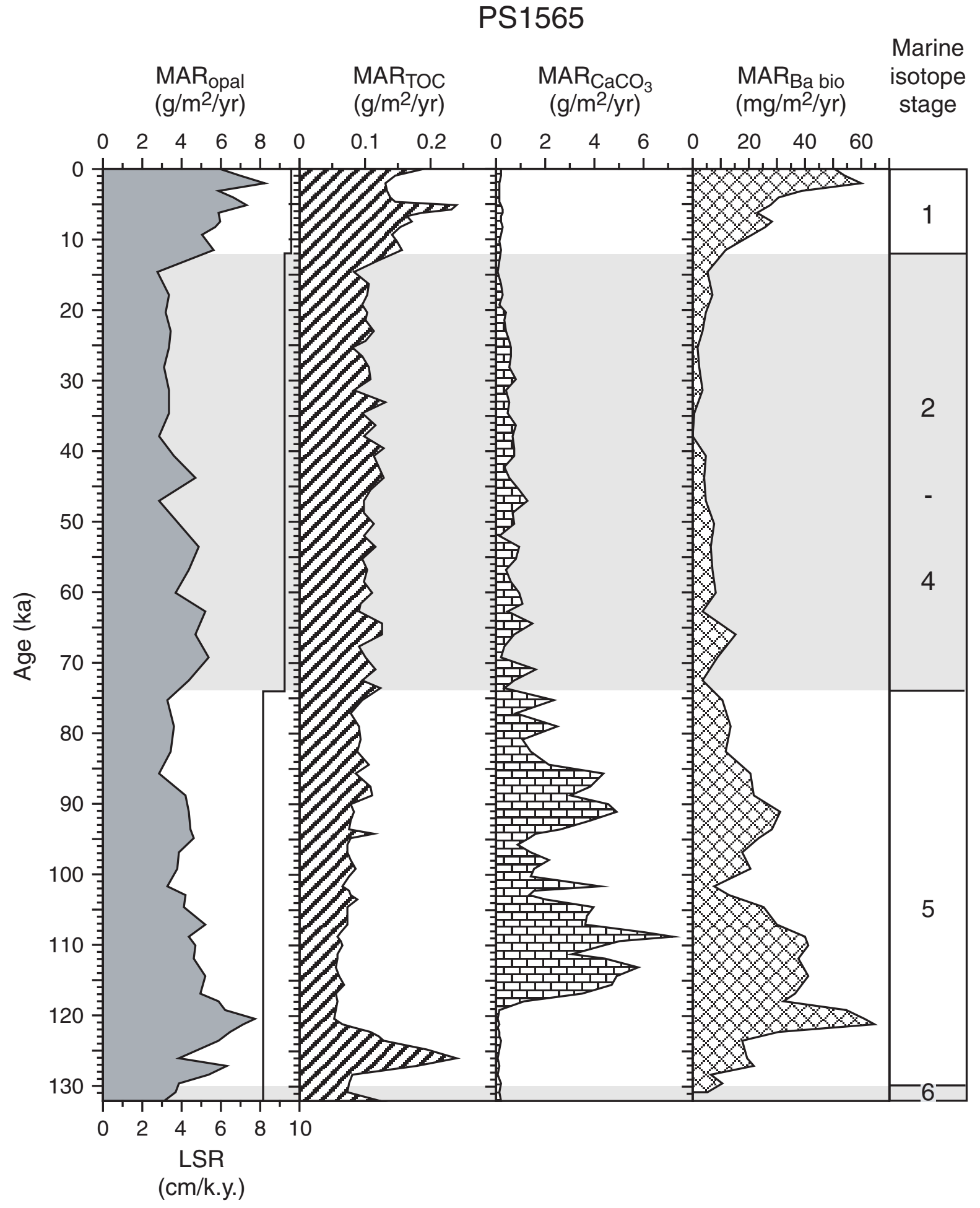




\section{C.-D. HILlenbrand AND D.K. FÜTTERER}

Figure F7. Correlation between the opal seabed preservation efficiency (the ratio of opal accumulation rate in the surface sediment, $\mathrm{MAR}_{\text {opal }}$, to the original opal depositional rate on the seabed) and the linear sedimentation rate (LSR) for Antarctic continental margin deposits in the Ross Sea (taken from DeMaster et al., 1996).

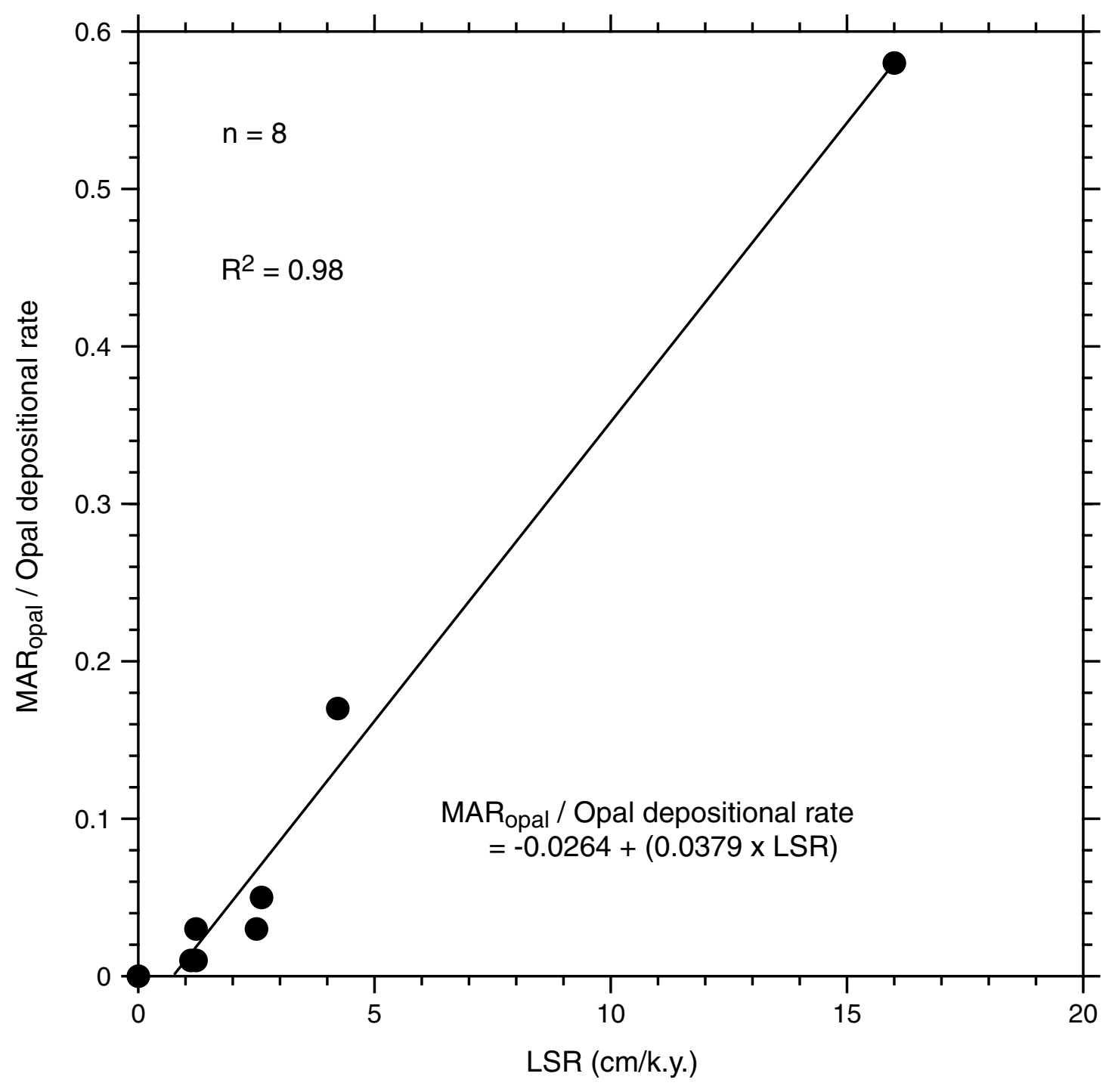


Figure F8. Estimated opal depositional rates (shaded) for sediments recovered at Sites 1095, 1096, and 1101 plotted vs. age. The bold lines depict opal depositional rates linearly integrated at time increments of 200 k.y. Stars at Site 1095 mark time intervals for which the opal depositional rates were equated with the opal accumulation rates $\left(\mathrm{MAR}_{\mathrm{opal}}\right)$.

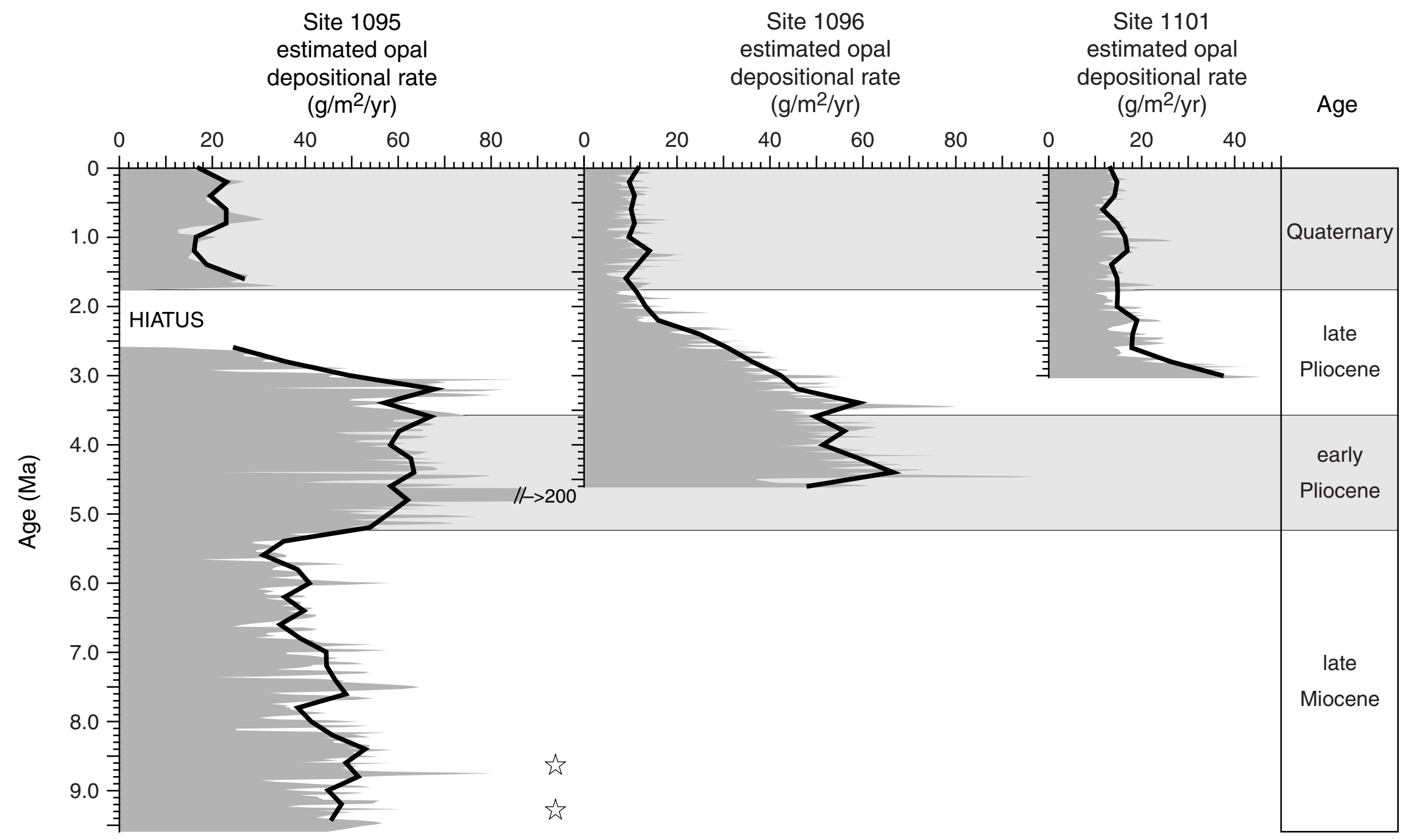




\section{C.-D. Hillenbrand AND D.K. FüTterer NeOgene To QuATERnARY OPAL Deposition}

Figure F9. Estimated opal depositional rates at Sites 1095 and 1096 (linearly integrated at time increments of 200 k.y.), derived long-term climatic evolution in the Bellingshausen Sea, and mean properties (production, flow, and temperature) of the Northern Component Water (NCW) throughout the last 9.5 m.y. Opal depositional rates at Sites 1095 and 1096 were spliced at $4.4 \mathrm{Ma}$ (thin stippled line) because of a late Pliocene hiatus and lower temporal resolution of samples at Site 1095. In the Bellingshausen Sea climatic curve, chronological uncertainty regarding early Pliocene warming because of another possible hiatus at Site 1095 (spanning the time interval from 6.140 to 5.040 Ma) are indicated by the bold stippled line. Details regarding development of the properties of NCW were taken from literature (see references in "Discussion," p. 8).

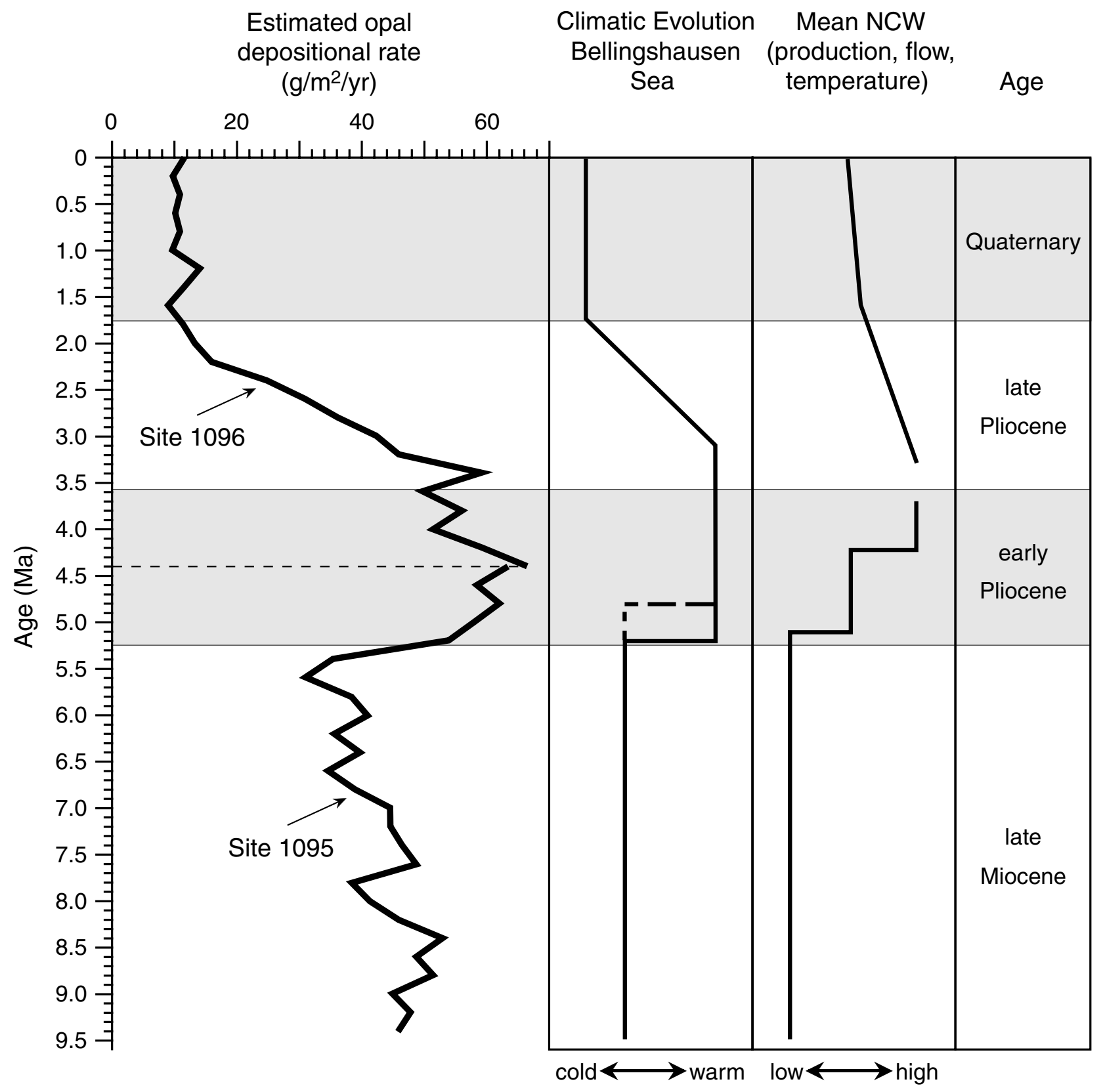




\section{C.-D. HILLENBRAND AND D.K. FÜTTERER}

NeOgENE TO QUATERNARY OPAL DEPOSITION

Table T1. Location, water depth, core recovery, and numbers of samples drilled on the continental rise west of the Antarctic Peninsula.

\begin{tabular}{lllcccc}
\hline \multicolumn{1}{c}{ Hole } & Latitude & Longitude & $\begin{array}{c}\text { Water } \\
\text { depth } \\
(\mathrm{m})\end{array}$ & $\begin{array}{c}\text { Core } \\
\text { recovery } \\
(\mathrm{m})\end{array}$ & Age & Samples \\
\hline $178-$ & & & & & & \\
$1095 \mathrm{~A}, 1095 \mathrm{~B}$ & $66^{\circ} 59.1^{\prime} \mathrm{S}$ & $78^{\circ} 29.3^{\prime} \mathrm{W}$ & 3853 & 554.06 & late Miocene-Quaternary & 318 \\
$1096 \mathrm{~A}, 1096 \mathrm{~B}, 1096 \mathrm{C}$ & $67^{\circ} 34.0^{\prime} \mathrm{S}$ & $76^{\circ} 57.8^{\prime} \mathrm{W}$ & 3164 & 673.27 & early Pliocene-Quaternary & 403 \\
$1101 \mathrm{~A}$ & $64^{\circ} 22.3^{\prime} \mathrm{S}$ & $70^{\circ} 15.7^{\prime} \mathrm{W}$ & 3291 & 215.75 & late Pliocene-Quaternary & 142 \\
\hline
\end{tabular}




\section{C.-D. Hillenbrand AND D.K. FÜTTERER}

NEOgENE TO QUATERNARY OPAL DEPOSITION

Table T2. Results of repeated opal measurements in regard to the analytical precision of the method.

\begin{tabular}{ccccc}
\hline $\begin{array}{c}\text { Core, section, } \\
\text { interval (cm) }\end{array}$ & Numbers & $\begin{array}{c}\text { Mean } \\
\left(\mathrm{wt} \% \mathrm{SiO}_{2}\right)\end{array}$ & $\begin{array}{c}\text { Standard } \\
\text { deviation } \\
\left(\mathrm{wt} \% \mathrm{SiO}_{2}\right)\end{array}$ & $\begin{array}{c}\text { Coefficient } \\
\text { of variation } \\
(\%)\end{array}$ \\
\hline $178-1095 \mathrm{~B}-4 \mathrm{H}-5,74-75$ & 12 & 19.8 & 2.7 & 3.9 \\
$178-1096 \mathrm{~A}-8 \mathrm{H}-7,16-18$ & 15 & 1.8 & 0.2 & 2.3 \\
$178-1096 \mathrm{~B}-9 \mathrm{H}-2,10-12$ & 14 & 2.9 & 0.5 & 4.4 \\
\hline
\end{tabular}

